Article

\title{
Regionally Divergent Patterns in Factors Affecting Municipal Waste Production: The Polish Perspective
}

\section{Elżbieta Antczak (D)}

Faculty of Economics and Sociology, University of Lodz, ul. POW 5/3, 90-214 Lodz, Poland; elzbieta.antczak@uni.lodz.pl; Tel.: +48-609-210-588

Received: 25 July 2020; Accepted: 23 August 2020; Published: 24 August 2020

check for updates

\begin{abstract}
This article attempts to identify factors impacting on the quantity of municipal waste in Polish 2478 communes (LAU-2), taking into account the variability of particular determinants' influence depending on their regional diversification. The analysis covers the years 2005-2018. The dependent variable is the volume of municipal waste in kg per capita, whereas the group of determinants include: economic and human development, uncontrolled dumping sites, population density, population at the working age, migration, tourism, urbanization, dwellings and housing, retail sales, entities, education, and investments in waste management. The geographically weighted regression with spatial error term (GWR-SEM) was employed in this study. The model enabled not only the specification of the waste production determinants, but also the analysis of the variability in the strength and direction of dependencies occurring between the examined variables in individual communes. The results proved that the higher the level of education, the less waste is generated (in north-central Poland); the business entities and working-age population are crucial for the waste quantity in communes of eastern Poland; the factors most important to regional range affecting the waste quantity are urban and business development, and most important to strength are higher education and the share of working-age individuals.
\end{abstract}

Keywords: municipal waste; Poland; geographically weighted regression with spatial error term; spatial processes; communes; sustainable development

\section{Introduction}

Municipal waste (MW) or municipal solid waste (MSW) is primarily produced by households, but also includes similar wastes from sources such as shops, offices, and public institutions (it does not include hazardous waste or waste from agriculture or industry) [1]. Although household MW accounts for only $10 \%$ of the total waste produced, its highly heterogenous and complex character makes it one of the most politically challenging and urgent environmental issues in Europe [2]. The Environmental Data Centre on waste notes that only $40 \%$ of MW is reused or recycled, and in some countries more than $80 \%$ still goes to a landfill [3,4]. The increasing volume of MW and the additional need for processing associated with the booming economy pose a serious risk to ecosystems, human health, well-being, and sustainability [5]. To regulate MW and to ensure minimal impact on the environment and human health, the management of MW became one of the 2030 Agenda for Sustainable Development goals [6] and a key objective of the Environmental Action Program for 2020 [7]. By 2030, the goals for establishing inclusive, smart, and sustainable growth include reducing "waste generation through prevention, reduction, recycling" and achieving "the environmentally sound management of chemicals and all wastes throughout their life cycle, in accordance with agreed international frameworks, and significantly reduce their release to air, water, and soil in order to minimize their adverse impacts on human health and the environment" [8]. The European Union (EU) agencies have noted that MW generation varies considerably among European countries [2]. For 2018, it ranged from $272 \mathrm{~kg}$ per 
capita in Romania to $766 \mathrm{~kg}$ per capita in Denmark (in 2005, it varied from $273 \mathrm{~kg}$ per person in Slovakia to $730 \mathrm{~kg}$ per capita in Ireland and Denmark). These variations in the amount of waste result from differences in consumption patterns and distribution among many sources of waste and economic wealth, but also depend on how MW is collected and managed. Poland has among the lowest levels of waste generated in Europe, with an average of $319 \mathrm{~kg}$ per person in 2005 and $329 \mathrm{~kg}$ per person in 2018, whereas the EU-28 produced $506 \mathrm{~kg}$ per capita on average in 2005 and $492 \mathrm{~kg}$ per person in 2018 [2]. However, the actual quantities of collected waste in Poland are greater than statistically pronounced. The Polish Ministry of the Environment reports that approximately $30 \%$ of MW is dumped illegally (in 2005-2018 in Poland approximately 73,000 tonnes of MW were collected during removal of uncontrolled dumping sites or incinerated in household furnaces) [9]. The major reasons for such behavior remain poor ecological awareness and low effectiveness of the waste management system (WMS) [10]. The Polish waste system is clearly not yet as developed as in many longer-standing EU countries [11]. It still lacks a waste monitoring control regime (including a comprehensive waste database) and a sufficient number of waste installations [12]. Moreover, the landfilling remains one of the most common methods of waste disposal in Poland, with as much as 53\% of MW sent to landfills (in 2018 there were 301 operating landfills for MW) [13]. Other methods such as composting, recycling, and incineration are also used, but on a negligible scale (comprising about $30 \%$ of the total amount of MW collected) [14]. Since 2013, local authorities (municipalities, communes) have been required to organize waste collection and maintain cleanliness in their administrative area, but every municipality could have their own set of waste rules, e.g., territorially-varied waste charge, different colors of trash bins, and limits on bin quantity [15]. The WMS in Poland remains very fragmented and split between the municipality (as a rule) and the property owners (as a matter of exception). Therefore, as an obstacle to implementation of innovative instruments of waste management (e.g., e-waste management systems, biological and thermal methods of municipal waste treatment, product payment, or tax policy), effective enforcement of these methods is not a simple task in Poland [16]. Moreover, such a system generates uncertainty about available waste data as well as notable problems with identifying determinants of waste generation and the range of their regional impact [17]. However, exploring and controlling the scope of waste generation is crucial in order to manage waste accordingly in the context of transitioning to a circular economy and sustainable development policy [18].

In the worldwide literature, waste generation has been examined using various factors in micro- or macroeconomic terms. In several studies, the amount of MW has been connected with household-level factors (i.e., economic status, per-capita income, size of household, employment rate, or location of household in rural or urban areas), commune-level factors, or with individual consumption patterns [19-24]. A wide range of scientific studies have found negative correlations between higher education at the societal level and the quantity of municipal waste [25-28]. Some authors have also analyzed the urban morphology, level of urbanization and urban development, tourism, and share of rural and urban population as driving forces in the analyzed phenomena [23,27,29]. Moreover, migration processes and culture are factors that can affect waste generation, but studies have been inconclusive [26,30,31]. Some papers have found population density, life expectancy, income inequality, retail sales, and the human development index to be positively correlated with waste production $[20,26,32]$. It also has been suggested that per-capita income, infant mortality, and socioeconomic status have a negative or no influence on the level of phenomena [21,26,30,33,34]. Finally, implementation of a waste disposal fee has been found to significantly decrease the amount of municipal waste by reducing illegal dumping and by minimizing the amount of landfilled waste [35,36]. In Poland, only a few studies (mainly theoretical) have investigated the factors determining municipal waste generation. Tałałaj (2011) analyzed the influence of selected socioeconomic factors, i.e., employment, economic status, entities, density population, share of population at working age, and salaries, on changes in waste generation across Polish districts [37]. Generowicz et al., (2011) employed a multicriteria analysis to plan waste management procedures in European cities or regions with a variety of waste disposal methods [38]. In Cheba's (2014) research, changes in urban waste generation were 
forecasted by accounting for the impact of various factors, i.e., infant mortality rate, life expectancy, average household size, and GDP per capita [39]. Ulfik and Nowak (2014) studied the determinants that affect the management of municipal waste in Poland by analyzing the adequacy of income covering the costs of the new legally required environmental waste management systems [40]. Kukuła (2016) applied a multidimensional comparative analysis to describe the diverse conditions impacting the municipal waste economy in Poland [41]. Klojzy-Karczmarczyk and Makoudi (2017) analyzed waste generation rates in urban and rural areas, estimating the causes of differences in the MW generation rate between Poland and other European countries [42].

All of the above exposed literature neglects the possible impact of spatial processes on the quantity of municipal waste. However, Keser et al. [43,44], Antczak [45], and Rybova [46,47] observed that waste generation may be correlated with a certain tendency towards the spatial autocorrelation of the process determinants. In Poland, MW transport and collection are operated by private companies, which sign contracts with both institutional and individual clients [14]. However, in 2018 only 298 entities were generally involved in municipal waste management [48]. Kołsut [49] and Cyranka et al. [50] concluded that the included companies dealing with the MW management are able to process only $33 \%$ of the total collected waste. Therefore, the municipalities must cooperate and form joint organizational structures for technical and economic reasons. This situation generates the transboundary shipment of waste over undetermined distances (from 2 to even 70 kilometers), and facilities' ranges of operation can therefore exceed commune boundaries. All these circumstances can result in spatial interactions [45]. Not accounting for the potential geographic interdependencies among units may result in biased and less-robust results [51]. Nonetheless, the analyses to date dealing with spatial variation in municipal waste determinants have been limited [43-50,52].

A review of published studies on the subject reveals the worldwide interest of scientists in municipal waste modelling. This paper contributes to the literature in several dimensions. Although the topic has been broadly studied at country level, studies addressing subnational units are still limited. Therefore, this research comprehensively investigates the determinants of the volume of municipal waste on a local level in Poland. This analysis covers all Polish communes $(\mathrm{N}=2478)$ over the years 2005-2018. The data concern the communes, as these are the smallest geographical units responsible for waste management in Poland for which data are available. Moreover, most literature to date has neglected the spatial processes (spatial dependencies, spatial heterogeneity, and spatial autocorrelation) in waste generation. However, the conducted data analysis revealed that the variability in waste generation is driven by spatial autocorrelation and geographical differences among municipalities. Therefore, the modelling in this paper was extended to spatial aspects of the territorially varied relationships between waste volume and its causes. Use of geographically weighted regression with spatial error term (GWR-SEM), which enables the monitoring and understanding of the regionally divergent influence of selected factors on the dependent variable, is another and an essential contribution in this paper. Integrating the spatial error component into the GWR controls for unobserved spatially-dependent phenomena in waste modelling, e.g., underestimation of the amount of waste illegally dumped, transported, or burned by inhabitants, or any other omitted processes closely connected to the levels and patterns of individual consumption. In order to diagnose potential misspecifications of the analysis, a robustness check from spatial, methodological, and temporal perspectives was implemented. Furthermore, the analysis accounted for a broad catalogue of factors, concerning education level, housing stock, population density, environmental awareness, urbanization, production, market demand, wealth, demographics, migration, tourism, and investment in the waste management system. Such a novel and multifaceted approach has not previously been undertaken, and its results should be relevant to formulating waste policy recommendations, especially for small-sized, regionally diversified economies.

The article consists of five sections. Section 2 describes a databank used in the study as well as the results of a preliminary analysis. Section 3 presents the method applied in the main part of the 
research. Section 4 includes the results and a discussion of them. The last section provides general conclusions and indicates some policy recommendations and further directions for research.

\section{Materials}

\subsection{Preliminarny Data Analysis}

Poland is divided into three regional classification levels (nomenclature of territorial units for statistics, NUTS) and two levels of local administrative units (LAU-1 and LAU-2) [53]. These LAUs are the building blocks of the NUTS and comprise the municipalities of the EU. Until 2016, in the EU, two levels of Local Administrative Units (LAU) existed: the upper LAU level (LAU-1, formerly NUTS-4) and the lower LAU level (LAU-2, formerly NUTS-5) [54]. As of 1 January 2020, in Poland, there are six regions (made up of provinces, NUTS-1), 16 provinces (NUTS-2), 73 sub-regions (made up of districts, NUTS-3), 380 districts (LAU-1), and 2478 communes (municipalities, LAU-2, with 944 urban areas, Figure 1).

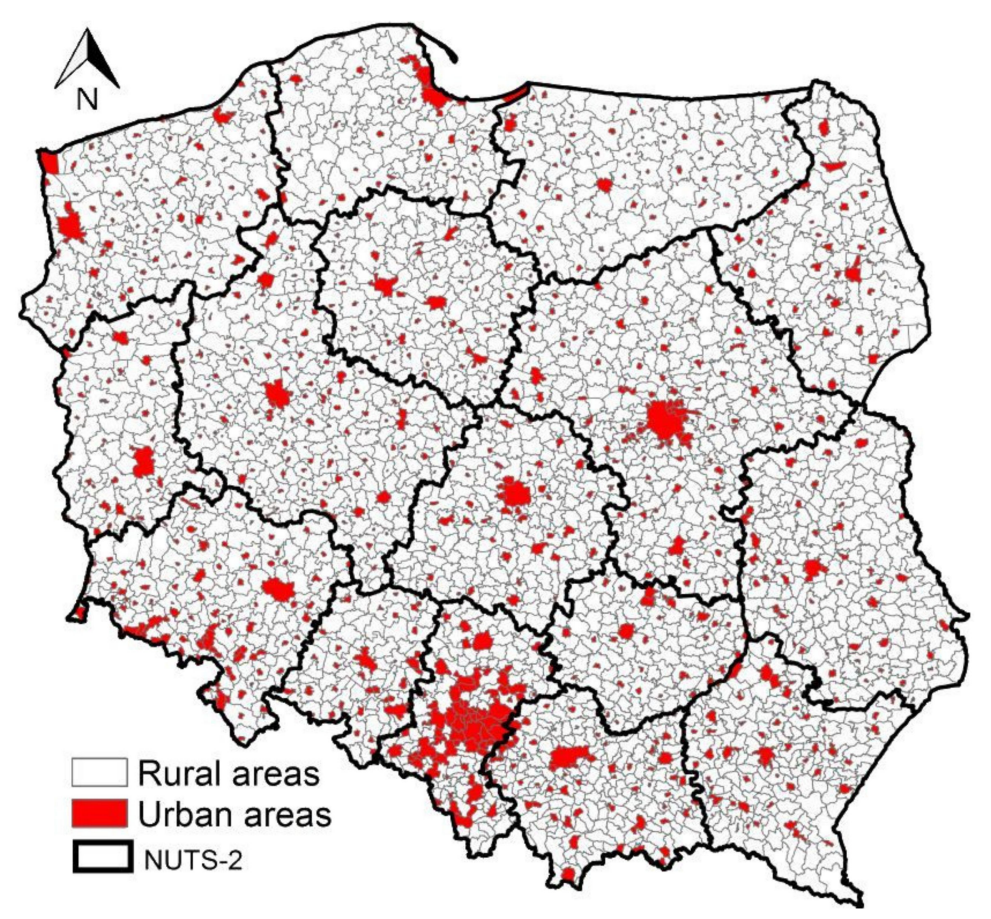

Figure 1. Urban and rural areas in Poland at LAU-2 level of administration. Note: to better capture and recognize the regional differences among municipalities, the NUTS-2 (provinces) boundaries were added to the maps in Figures 1,4,6-8.

This paper focuses on the LAU-2 level, as its units are those on which the new "Act on maintaining cleanliness and order in municipalities" has placed responsibility for waste collection and disposal [15]. The data cover quantity of MW in kilograms per person from 2005 to 2018 was collected from the Polish Local Data Bank of the Central Statistical Office (CSO). Before 2005, information was available only at the LAU-1 level.

Throughout the studied period, the quantity of collected MW in kilograms per person in analyzed Polish communes was characterized by a steady increase (by $2.5 \%$ per year)-from $178 \mathrm{~kg}$ per capita in 2005 to $253 \mathrm{~kg}$ in 2018, an overall increase of 43\%, as seen in Figure 2. However, since 2012, the data show an acceleration of the process-an increase of more than 5\% in MW per capita from year to year. 


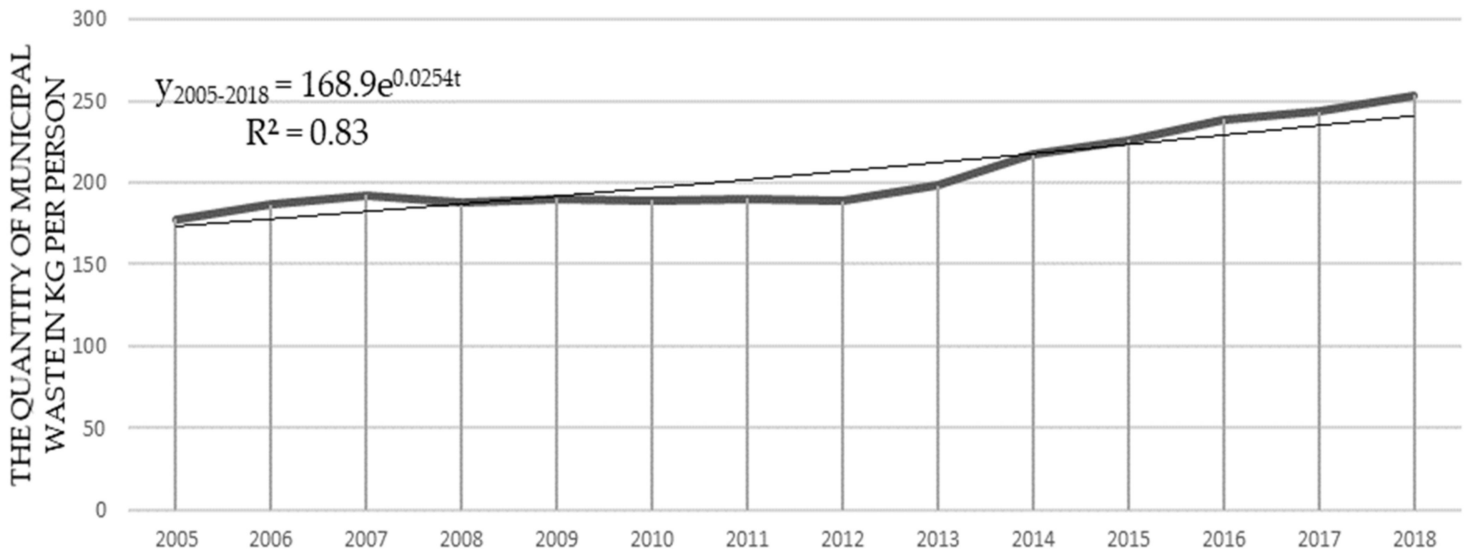

Figure 2. Dynamics of the quantity of municipal waste collected in Polish communes in the years 2005-2018, in kg per capita. Note: the growth (exponential) regression functions for two time periods (2005-2011 and 2012-2018) are given by: $\mathrm{y}_{2005-2011}=181.8 \mathrm{e}^{0.08 \mathrm{x}}, \mathrm{R}^{2}=0.44$ and $\mathrm{y}_{2012-2018}=182.4 \mathrm{e}^{0.05 \mathrm{x}}$, $\mathrm{R}^{2}=0.97$.

From a regional perspective, municipalities in Poland are characterized by decreasing but still large variation in the amount of waste generated per capita (coefficient of variation exceeds 50\%), as seen in Figure 3.

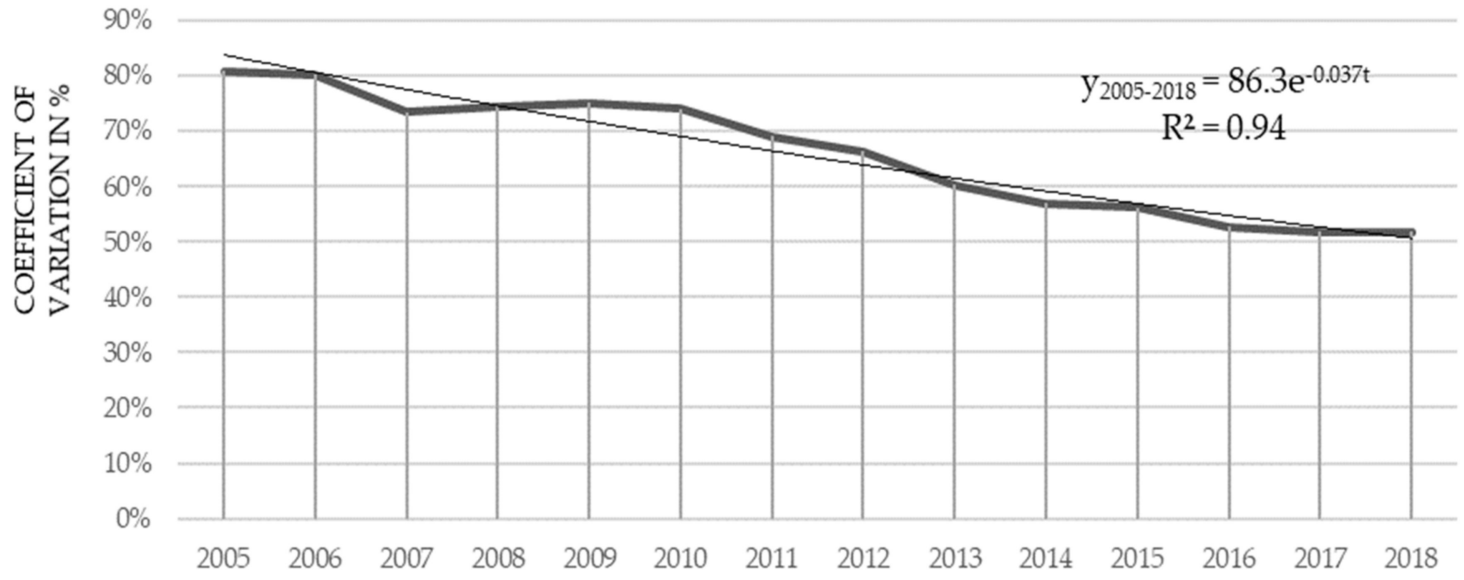

Figure 3. Regional disparities in quantity of municipal waste collected in Polish communes in the years 2005-2018 measured by coefficient of variation, in \%. Note: coefficient of variation (relative standard deviation) is a statistical measure of the dispersion of data points around the mean (it is the ratio of the standard deviation to the mean). The higher the coefficient of variation, the greater the level of dispersion around the mean. It is generally expressed as a percentage [45].

In 2005, noticeably more waste was generated only by the residents of cities. However, with time, the process unfolded at different rates for rural areas and cities of different sizes or income levels. Moreover, in 2018, wealthier, highly populated units of Poland (especially in the north and the southwest) were associated with a greater amount of collected MW than in those zones in 2005. In general, we observed spatiotemporal changes in the phenomena (Figures 2 and 3), and from 2005 to 2018 the data showed a downward spatial trend towards the east of Poland and an increasingly notable upward tendency in the northwestern areas (Figure 4).

This noticeable regional variation in waste volume observed among communes may arise from regional inequalities in socioeconomic factors and consumption levels in Polish households as well as from spatial dependency of the process determinants. 


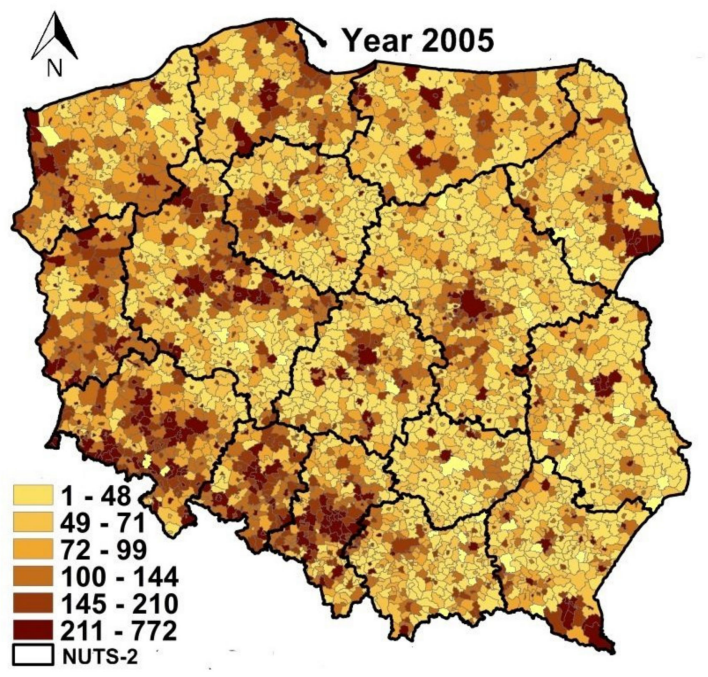

(a)

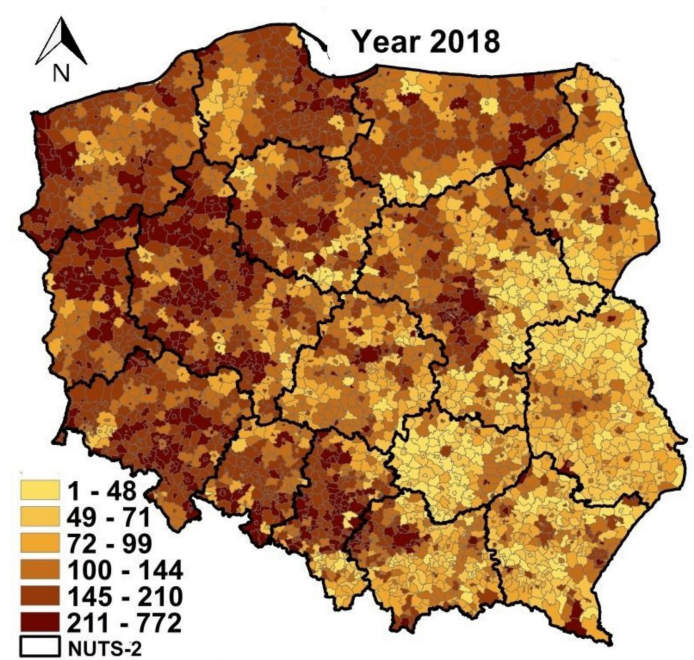

(b)

Figure 4. Regional disparities among Polish communes in the amount of collected municipal waste (kg per capita) in year 2005 (a) and 2018 (b). Note: to capture the differences in waste amount between 2005 and 2018, the same scale was used for each year on the maps; the average amount in 2005 was 178 $\mathrm{kg}$ per capita, and in 2018 it was $253 \mathrm{~kg}$ per capita; the descriptive statistics of the waste amount for each year of the analysis is included in Table A1 in the Appendix A.

\subsection{Potential Determinants of MW Volume in Poland}

The waste generation process has been strongly related to economic and sociodemographic variables, but the primary ones are seen in the lack of effective restructuring of municipal waste management systems, low awareness of inhabitants, and little-controlled regional variability of waste stream production (spatial processes). Taking into account the availability and comparability of Polish data and those variables defined in the literature, this paper suggests 14 factors that could be possible determinants of the phenomena. The data were collected from the Polish Local Data Bank in the Central Statistical Office and were classified into categories (Table 1).

The catalogue of variables is incomplete because of the gaps during the 2005-2018 period, with panel modelling being impossible for this dataset (Table 1). This problem is an additional reason for employing the GWR function to explain the process of municipal waste generation in Poland. In the further estimations, the values of all the variables were averaged over time and expressed in natural logarithms. The GWR4-Semiparametric Geographically Weighted Regression Release 1.0.90 (GWR 4.0.90) and ArcGIS 10.6 software were used in this analysis.

Table 1. Possible factors of the municipal waste generation in Poland.

\begin{tabular}{|c|c|c|c|}
\hline Variable & Description & Time Span & Category \\
\hline UDS & $\begin{array}{l}\text { Uncontrolled dumping sites } \\
\text { per } 100 \mathrm{~km}^{2}\end{array}$ & $2008-2018$ & $\begin{array}{c}\text { Awareness/human } \\
\text { development }\end{array}$ \\
\hline PD & Population density in people per $1 \mathrm{~km}^{2}$ & 2005-2018 & Demography \\
\hline WA & Population at the working age in $\%$ & 2005-2018 & $\begin{array}{l}\text { Demography/ } \\
\text { economy/human } \\
\text { development }\end{array}$ \\
\hline M & $\begin{array}{l}\text { Registrations for permanent residence } \\
\text { per } 1000 \text { people }\end{array}$ & 2005-2017 & Migration \\
\hline $\mathrm{TO}$ & Nights spent by tourists per 1000 people & 2005-2018 & Tourism \\
\hline UR & $\begin{array}{l}\text { Urban and rural area: } 2 \text {-urban areas, } \\
\text { 1—rural areas }\end{array}$ & 2005-2018 & $\begin{array}{c}\text { Urbanization/urban } \\
\text { development/urban } \\
\text { morphology }\end{array}$ \\
\hline
\end{tabular}


Table 1. Cont.

\begin{tabular}{|c|c|c|c|}
\hline Variable & Description & Time Span & Category \\
\hline $\mathrm{D}$ & Dwelling stocks per 1000 population & 2005-2017 & $\begin{array}{l}\text { Dwellings and } \\
\text { housing/living } \\
\text { conditions }\end{array}$ \\
\hline MA & $\begin{array}{l}\text { Permanent marketplaces of retail sales } \\
\text { per } 100,000 \text { people }\end{array}$ & 2005-2017 & $\begin{array}{l}\text { Sales retail/ } \\
\text { consumption }\end{array}$ \\
\hline $\mathrm{EE}$ & $\begin{array}{c}\text { Entities of the national economy entered } \\
\text { in the REGON system } \\
\text { per } 10,000 \text { people }\end{array}$ & 2005-2017 & $\begin{array}{c}\text { Economy/ } \\
\text { development }\end{array}$ \\
\hline ED & $\begin{array}{l}\text { Higher education graduates } \\
\text { per } 10,000 \text { people }\end{array}$ & 2005-2018 & $\begin{array}{l}\text { Education/ } \\
\text { awareness/human } \\
\text { development }\end{array}$ \\
\hline IN & $\begin{array}{l}\text { Investments in waste municipal } \\
\text { management system } \\
\text { in PLN per capita }\end{array}$ & 2005-2018 & $\begin{array}{l}\text { Investments/ } \\
\text { economy }\end{array}$ \\
\hline URP & $\begin{array}{c}\text { Proportion of urban and rural } \\
\text { population in } \%\end{array}$ & 2005-2018 & $\begin{array}{l}\text { Urbanization/ } \\
\text { demography }\end{array}$ \\
\hline $\mathrm{IM}$ & $\begin{array}{l}\text { Infant mortality rate as the number of } \\
\text { deaths per } 1000 \text { live births of children } \\
\text { under one year of age }\end{array}$ & 2005-2018 & $\begin{array}{c}\text { Demography/ } \\
\text { living condition/health }\end{array}$ \\
\hline LE & Life expectancy in years at age 0 & 2005-2018 & $\begin{array}{l}\text { Demography/living } \\
\text { condition/health }\end{array}$ \\
\hline
\end{tabular}

\section{Methods}

\subsection{Moran's I Spatial Autocorrelation Indices}

To explore the regional autocorrelation in the amount of annually collected waste, the global (1) and local (2) Moran's I statistics (ESDA, explanatory spatial data analysis) were applied [55].

$$
I=\frac{\sum_{i=1}^{n} \sum_{j=1}^{n} w_{i j}\left(x_{i}-\bar{x}\right)\left(x_{j}-\bar{x}\right)}{\sum_{i=1}^{n}\left(x_{i}-\bar{x}\right)^{2}},
$$

where $n$ is the number of observations (spatial units, here 2478 communes); $x_{i}$ and $x_{j}$ are values of the variable $x$ in commune $i$ and $j$, respectively; $\bar{x}$-is the average of the variable $x$ over all spatial units; and $w_{i j}$ represents the elements of diagonal matrix $(n \times n)$ of spatial weights with non-zero diagonal elements $\mathbf{W}$, having weights matrix $\mathbf{W}$ standardized in rows. This means that each element in the th row is divided by the sum of values in that row. Elements of the row-standardized matrix take values between zero and one. The sum of values in a row is always one [56]. The value of Moran's I statistic varies from -1 to 1 . If adjacent spatial units are similar to one another, the value of the statistic is positive. If objects are different, the value of the statistic is negative. In the event that there is no correlation between adjacent values, the expected value is close to zero. To verify hypotheses concerning spatial autocorrelation, the so-called randomization tests were performed (for the algorithm of this test [55]). To reveal local spatial regimes, local indicators of spatial association (LISA) were calculated; the global indicator (1) assumes homogeneity across the spatial sample, but local measures (2) are more powerful to reveal geographically-varied patterns [55]:

$$
I_{\text {LISA }}=\frac{n\left(x_{i}-\bar{x}\right) \sum_{j=1}^{n} w_{i j}\left(x_{i}-\bar{x}\right)\left(x_{j}-\bar{x}\right)}{\sum_{i=1}^{n}\left(x_{i}-\bar{x}\right)^{2}} .
$$




\subsection{Geographically Weighted Regression with Spatial Error Term}

Classical modelling of spatial data assumes stationary relationships between dependent and independent variables and therefore homoscedasticity of the random error of OLS (ordinary least squares) regression:

$$
y_{i}=\beta_{0}+\sum \beta_{k} x_{i k}+\varepsilon_{i}
$$

where $y_{i}$ is the dependent variable at location $i ; x_{i k}$ is the $k$-th independent variable at location $i ; \beta_{i 0}$ is the intercept for location $i ; \beta_{i k}$ is the local regression coefficient for the $k$-th independent variable at location $i$; and $\varepsilon_{i}$ is the random error at location $i$.

The OLS approach (3) provokes the same response in all parts of the studied region. In practice, spatial data are often heterogeneous and therefore more complicated in their structure. As they are diverse in features and size, relationships between variables may be geographically varied [57]. The literature then indicates using the geographically weighted regression (GWR) model, which controls spatial heterogeneity and spatially-varying relationships [58]:

$$
y_{i}=\beta_{0}\left(u_{i}, v_{i}\right)+\sum \beta_{k}\left(u_{i}, v_{i}\right) x_{i k}+\varepsilon_{i}
$$

where $\left(u_{i}, v_{i}\right)$ are the coordinates of location.

The coefficients $\beta_{k}$ in GWR are functions of spatial location and take different values for each point (here, for each analyzed commune), and as a result, this model enables identification of the variability of regression coefficients in the geographical space.

The estimator for GWR (4) takes the form of:

$$
\hat{\boldsymbol{\beta}}_{k}\left(u_{i}, v_{i}\right)=\left(\mathbf{X}^{T} \mathbf{W}\left(u_{i}, v_{i}\right) \mathbf{X}\right)^{-1} \mathbf{X}^{T} \mathbf{W}\left(u_{i}, v_{i}\right) \mathbf{Y}
$$

where $\hat{\boldsymbol{\beta}}_{k}$ represents an estimate of $\boldsymbol{\beta}_{\mathbf{k}}$ that is an $n \times m$ matrix with elements $\hat{\boldsymbol{\beta}}_{k}\left(u_{i}, v_{i}\right)$; and $\mathbf{X}^{T} \mathbf{W}\left(u_{i}, v_{i}\right) \mathbf{X}$ is the geographically weighted variance-covariance matrix (6). Most commonly, the coordinates $\left(u_{i}, v_{i}\right)$ indicate location $i^{\prime}$ s geographic center and the location of each point where an observation was made, so that $\mathbf{W}\left(u_{i}, v_{i}\right)=$ diag elements $\left(w_{i 1}, w_{i 2}, \ldots, w_{i n}\right)[59]$. The $\mathbf{W}\left(u_{i}, v_{i}\right)$ matrix is as follows:

$$
\mathbf{W}\left(u_{i}, v_{i}\right)=\left[\begin{array}{ccc}
\mathbf{w}_{1}\left(u_{i}, v_{i}\right) & 0 & 0 \\
0 & \ldots & 0 \\
0 & 0 & \mathbf{w}_{n}\left(u_{i}, v_{i}\right)
\end{array}\right] .
$$

The estimation of parameters is achieved by using the weighted least square method (WLS) and attributing individual weights to each unit according to the assumption that observations near one another have a greater influence on their estimations than do units farther apart, which means that the impact decreases with distance [60]. In practice, the weight assigned to each observation is based on a distance decay function centered around observation $i$, and the weighting scheme is one of the most important steps in the analysis because it actually determines the results of modelling [61]. The distance is calculated with a kernel function (bandwidth) based on the proximities between the regression point $i$ and the data around it. Several options are possible for estimation of the bandwidths in GWR [62].

In this study, the adaptive type of the spatial kernel was used to provide geographic weighting in the model [63]. A key coefficient in the kernel is the bandwidth, which controls the size of the kernel [64]. The corrected Akaike information criterion (AIC) method was applied to determine the bandwidth (the bandwidth for which the statistic takes the lowest values is considered to be optimal), which accounts for model parsimony (i.e., a trade-off between prediction accuracy and complexity) as is recommended in the literature [61,62].

The pseudo-stepwise procedure was used to explore the data with a limited number of OLS regressions (benchmarks), which are compared to their GWR counterparts [61]. To test for multicollinearity in OLS, the variance inflation factor measure (VIF) was used [65]. The VIF represents 
a considerably better approach than studying the simple correlation values, because it indicates the coefficients for which collinearity is a problem [66]. A VIF $>2.5$ shows that the variable is affected by collinearity and may be problematic in regression, while a VIF $>10$ is interpreted as an indicator that the correlation among the variables is so high that the standard error of the regression coefficient is excessively inflated and the coefficient is likely to be poorly estimated [67]. To identify the spatial non-stationarity, Koenker's statistic (Koenker's studentized Breusch-Pagan test) is applied. The null hypothesis for this test is that the model is stationary [68]. To measure the local goodness-of-fit, local R-squared values were reported (interpreted as the proportion of dependent variable variance accounted for by the model).

Given estimations of OLS and GWR (5), the models' residuals were tested for spatial error autocorrelation [69] using Moran's I or Lagrange Multiplier test [55]. Rejection of a null hypothesis of spatial error independence suggests that regression residuals are not spatially random, and the GWR spatial autoregressive error model (GWR-SEM) is a way to address spatial heterogeneity and spatial error autocorrelation (as it accrued in this research paper). The GWR regression (5) was re-estimated with the spatially filtered variables $\tilde{\mathbf{X}}$ and $\tilde{\mathbf{Y}}$. The dependent and explanatory variables were transformed to filter spatial error autocorrelation using $\lambda$ :

$$
\hat{\boldsymbol{\beta}}_{k}\left(u_{i}, v_{i}\right)=\left(\tilde{\mathbf{X}}^{T} \tilde{\mathbf{W}}\left(u_{i}, v_{i}\right) \tilde{\mathbf{X}}\right)^{-1} \tilde{\mathbf{X}}^{T} \tilde{\mathbf{W}}\left(u_{i}, v_{i}\right) \tilde{\mathbf{Y}}
$$

with a filtering mechanism: $\tilde{\mathbf{X}}=(\mathbf{I}-\lambda \mathbf{W}) \mathbf{X}$ and $\tilde{\mathbf{Y}}=(\mathbf{I}-\lambda \mathbf{W}) \mathbf{Y}$.. The estimation method for the GWR-SEM used in this study was based on the Cochrane-Orcutt method of filtering variables, typically divided into four steps [70]: (1) estimate parameters of the GWR (5); (2) use the residuals from the GWR model and estimate the parameter lambda $(\lambda)$ based on them; (3) transform the outcome and explanatory variables using a filtering mechanism $[(\mathbf{I}-\lambda \mathbf{W})]$; and (4) again estimate the GWR using the filtered variables.

The localized estimations of the final model (7) were visualized on the maps, as they play a key role in interpreting the obtained results and understanding the studied relationships with a spatial perspective [71].

\section{Results and Discussion}

\subsection{Spatial Dependencies in MW among Polish Communes}

The data presented on maps in Figure 4 confirm that waste generation in Poland groups municipalities into homogeneous areas. This may be associated with a certain tendency towards the spatial dependency of the process determinants. According to the global Moran's I statistic (1), communes were spatially autoregressive - the volume of MW in one municipality was correlated with the waste quantity in another unit. This finding means local clustering of units with similar amounts of waste and unbalanced regional patterns of waste generation (Figure 5).

Moreover, the positive spatial association rose over time, indicating that the effects of interregional dependency have increased in significance and that communes' tendency toward agglomeration in terms of waste amount accelerated.

The indices (2) of local Moran's I spatial association (LISA) detect the sprawl and changes in spatial clustering of communes in term of the quantity of municipal waste in two years: 2005 and 2018 (Figure 6).

The LISA results indicate that in 2018 there was increased similarity in waste generation among the communes when compared to 2005 (Figure 6). Irrespective of the year of the analysis, the highest spatial concentration of units (high-high LISA clusters) with the greatest amount of municipal waste (from $145 \mathrm{~kg}$ per person to $772 \mathrm{~kg}$, Figure 4) occurred in southwestern Poland and in larger urban zones. However, in 2018, eastern Poland presented agglomerations of municipalities with low levels of waste production (from $49 \mathrm{~kg}$ to $99 \mathrm{~kg}$ per person, Figure 4), whereas in 2005 this pattern of low-low 
LISA indices was blurred and spread over the central and eastern parts of the country. Moreover, in the analyzed time period, notable changes were observed in the number of municipalities with the highest level of phenomena; that is, more high-high clusters (340 units) were identified in 2018, compared to 164 in 2005.

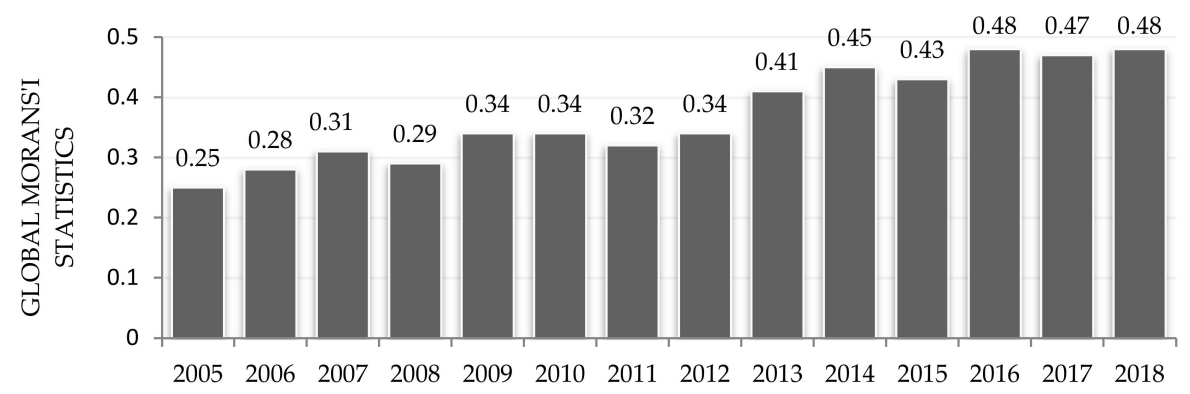

Figure 5. The global spatial autocorrelation of annually collected municipal waste measured by Moran's I statistic in the years 2005-2018. Source: own elaboration in ArcGIS (ArcMap 10.6). Note: all the values of Moran's I were statistically significant at level $\alpha=0.05^{* * *}$; the first order queen criteria and row standardized spatial matrix was used [56].

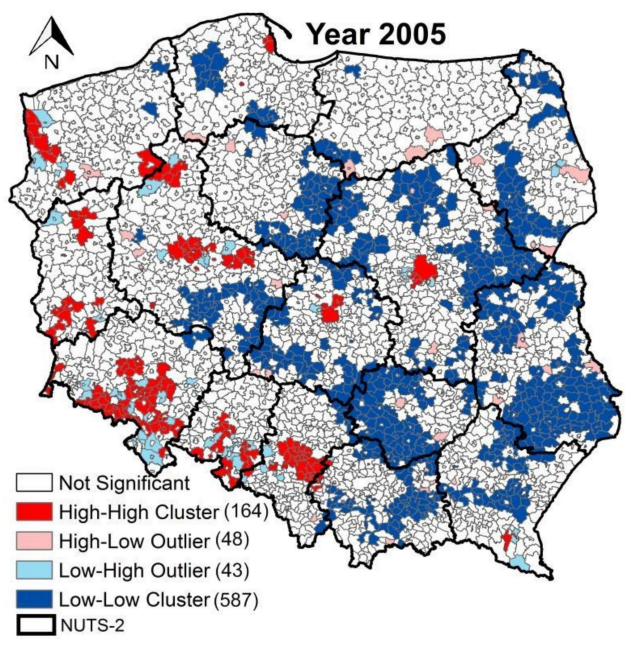

(a)

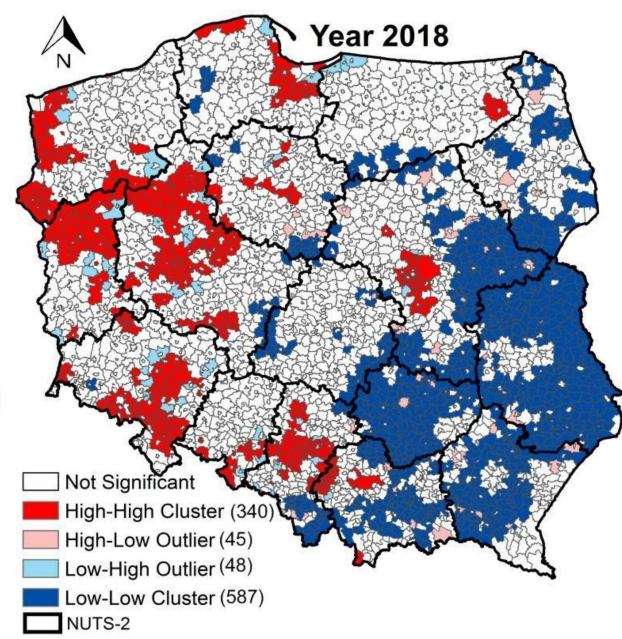

(b)

Figure 6. The local spatial autocorrelation of waste generation measured by local Moran's I statistic for year 2005 (a) and 2018 (b). Source: own elaboration in ArcGIS (ArcMap 10.6). Note: significance level: $\alpha=0.05^{* * *}$; the first order queen criteria and row standardized spatial matrix was used [56]. In brackets the number of units characterized by the statistically significance LISA indices is indicated.

In 2018, the size of clusters of high levels of waste generation spread around surrounding communes in the west and south of Poland. On the other hand, the size of low-low clusters shrank in the center but increased in eastern Poland, including rural rather than urban areas. Surprisingly, the analysis (Figure 6) presents a noticeable number of different-sized cities with non-significant autocorrelation in terms of MW distribution.

\subsection{GWR-SEM Diagnostics}

In order to compare the results of the GWR models, the parameters of the global regression analysis (OLS) were also estimated. The results included in Table 2 reveal that the selected factors (by correlation and variance inflation factors analysis) unreservedly support a valid relationship with the dependent variable with no multicollinearity (in the global modelling, the VIF did not exceed 2.5 
for any variable [72]). The urban development (UR), housing stock (D), nights spent by tourists (TO), population of working age (WA), registered entities of the national economy (EE), and registration for permanent residence $(\mathrm{M})$ were statistically significant and positively correlated with the dependent variable. Only higher education graduates (ED) decreased the amount of municipal waste in Poland. In the regression, the variables were log-transformed, as the log-log model better describes the analyzed relationship than do other types of functions.

Table 2. Results of global model (OLS) estimations.

\begin{tabular}{ccccc}
\hline Variable & Coefficient & Standard Error & t-Student & VIF \\
\hline Intercept & $-8.93^{* * *}$ & 0.57 & -15.78 & - \\
UR (urban/rural) & $0.11^{* * *}$ & 0.01 & 10.15 & 2.3 \\
D (dwellings) & $0.50^{* * *}$ & 0.06 & 8.04 & 1.6 \\
TO (tourism) & $0.02^{* * *}$ & 0.004 & 4.93 & 1.3 \\
WA (working age) & $4^{* * *}$ & 0.27 & 17.54 & 1.8 \\
EE (entities) & $0.41^{* * *}$ & 0.03 & 12.82 & 2.4 \\
M (migration) & $0.13^{* * *}$ & 0.02 & 5.50 & 1.3 \\
ED (education) & $-0.19^{* * *}$ & 0.04 & -4.39 & 1.1
\end{tabular}

Note: *** statistically significant at level $\alpha=0.05$; the VIF values for population density, urban and rural population, and permanent marketplaces exceeded 5; the uncontrolled dumping sites, infant mortality rate, and life expectancy have no statistically significant influence on waste generation; local multicollinearity problem was subsequently solved and processed with principal components method (PCA) [73], according to which all the components explained over $90 \%$ of the total variance (the correlation matrix, all results of VIF and principal components analysis are available by e-mail). Statistics of explanatory variables are presented in Table A2 in the Appendix A.

The preliminary ESDA measurements (Figures 5 and 6) indicated that municipal waste generation in Polish communes is detected by spatial dependencies. Moreover, the Koenker (BP) statistic indicates that the modelled relationships were not consistent (non-stationary and heterogeneous) in geographic space (Table 3). Both of those tests reveal that the geographically weighted regression performs better and further implies the importance of spatial non-stationarity in waste data sets. However, the Moran's I statistic revealed no statistically significant spatial autocorrelation only in GWR-SEM residuals (in contrast to OLS and GWR regression, the applied model embraced the spatial dependence in data, initially detected by global and local Moran's tests- Figures 5 and 6). Moreover, the employed GWR-SEM significantly improved all the results and overcame other misspecifications of OLS and GWR regressions (Table 3). The value of AIC (Akaike Information Criterion) declined from -1692.4 in the global model to -2808.9 in the GWR, and finally achieved the lowest value for GWR-SEM (-2859.5). The Jarque-Bera statistic indicated that the residuals were normally distributed. The total $\mathrm{R}$-squared value (the average value of the adjusted local R-squared indices) increased from 0.54 in OLS to 0.76 in GWR and rose to 0.97 for GWR-SEM (Table 3). The local R-squared values indicate that the local regression models (GWR-SEM) predict the dependent process well and perform well in the analysis (the goodness-of-fit ranges from 0.89 to 0.99 ), as seen in Figure 7.

Table 3. Diagnostic tests computed for ordinary least squares (OLS) and geographically weighted regressions (GWR, GWR-SEM).

\begin{tabular}{cccc}
\hline Diagnostics & OLS & GWR & GWR-SEM \\
\hline Bandwidth & - & $26,635.3$ & $34,636.4$ \\
R-Squared & 0.54 & 0.77 & 0.98 \\
Adjusted R-Squared & 0.52 & 0.76 & 0.97 \\
Residual Sum of Square & 102.9 & 58.3 & 51.4 \\
AIC & -1692.4 & -2808.9 & -2859.5 \\
Moran's I & $0.39^{* * *}$ & $0.09 * * *$ & 0.005 \\
Koenker (BP) Statistic & $14,120^{* * *}$ & - & - \\
Jarque-Bera Statistics & $198.3^{* * *}$ & 3.34 & 2.17 \\
\hline
\end{tabular}

Note: ${ }^{* * *}$ statistically significant at level $\alpha=0.05$. Yu noted that GWRs usually produce better fitting to data than do global OLS, as they control for spatial heterogeneity, spatial autocorrelation, and spatial dependency of the analyzed relationships [74]. 


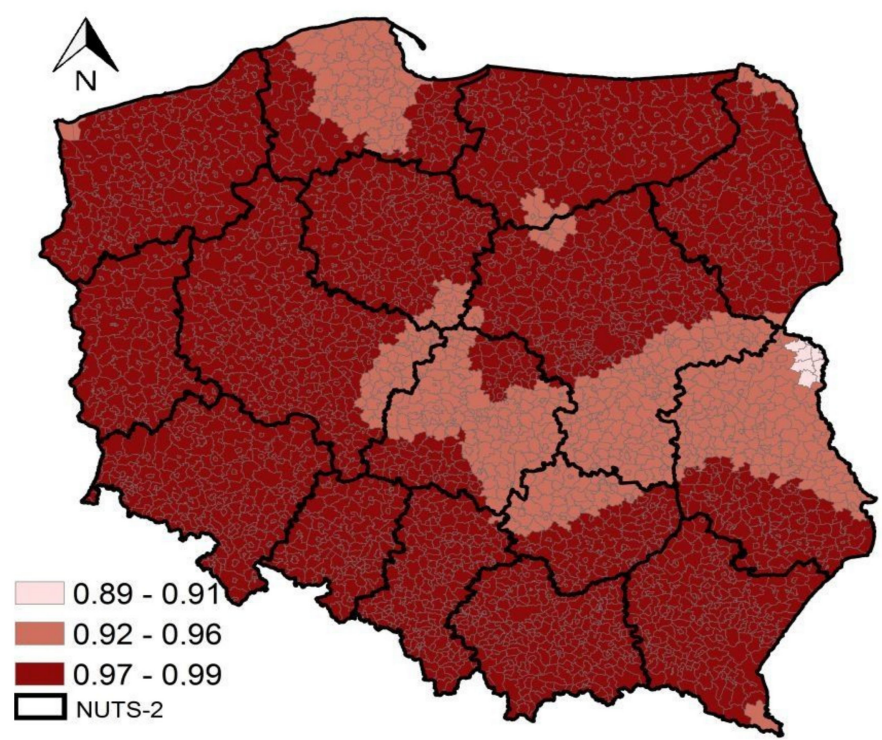

Figure 7. The local R-squared goodness of fit measure computed by GWR-SEM. Source: Own elaboration in GWR4 and ArcGIS (ArcMap 10.6).

\subsection{Modelling Results and Discussion}

The coefficients estimated by GWR-SEM vary greatly with communes in space. This result implies a noticeable spatial non-stationarity of the relationship between selected determinants and the amount of municipal waste collected yearly. The regression coefficients of each factor have both a positive and a negative value, which indicates that the relevance between each influencing variable and MW in a given LAU-2 has varying direction and strength in space. The maps in Figure 8 present the local values of coefficients and its significance level of the GWR-SEM models (Table A3 in the Appendix A includes summary statistics for varying local coefficients).

(a)

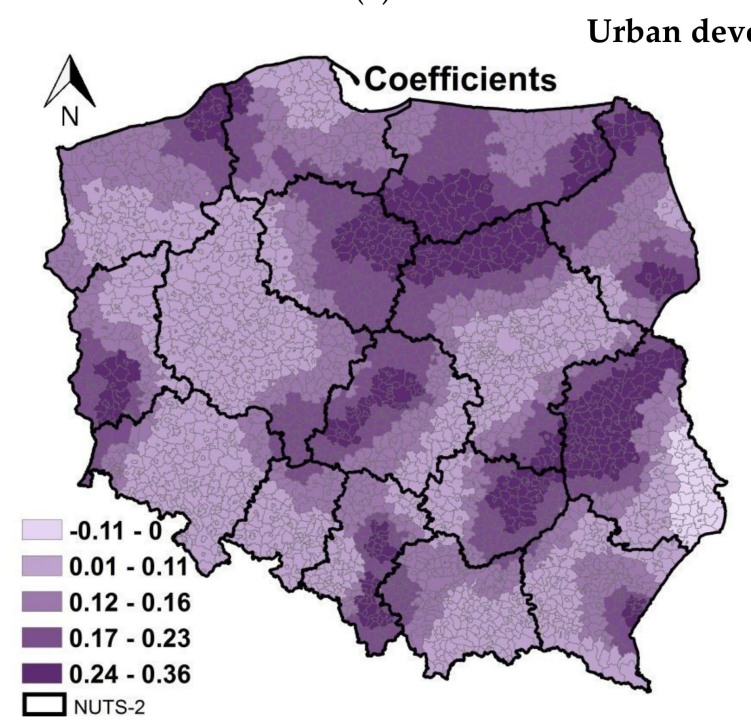

(b)

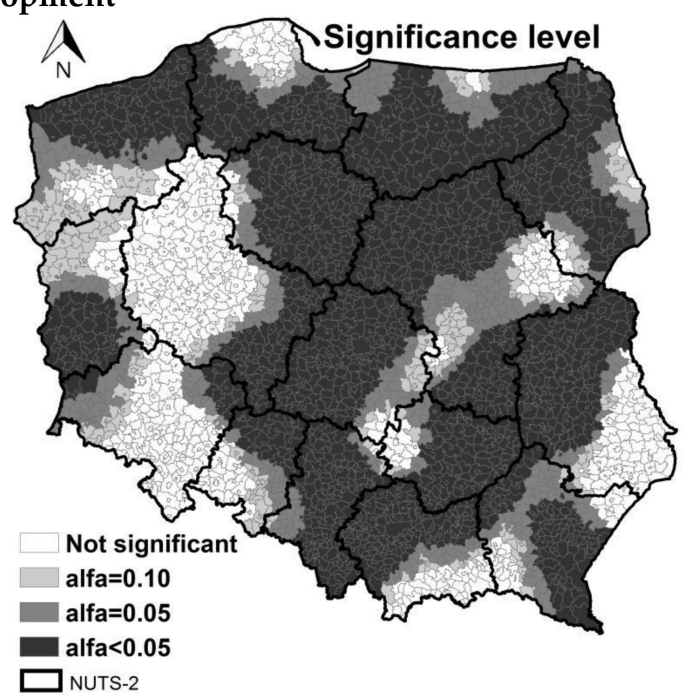

Figure 8. Cont. 


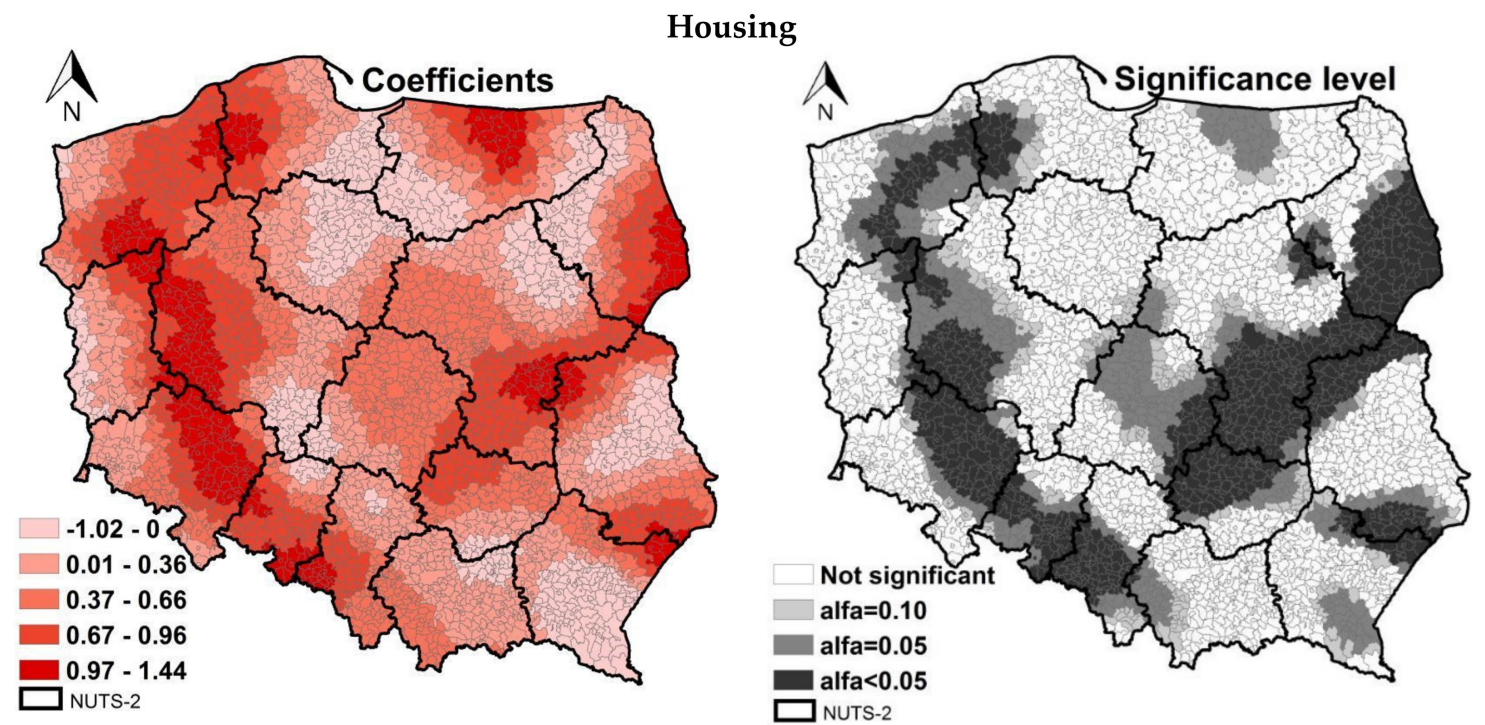

Tourism
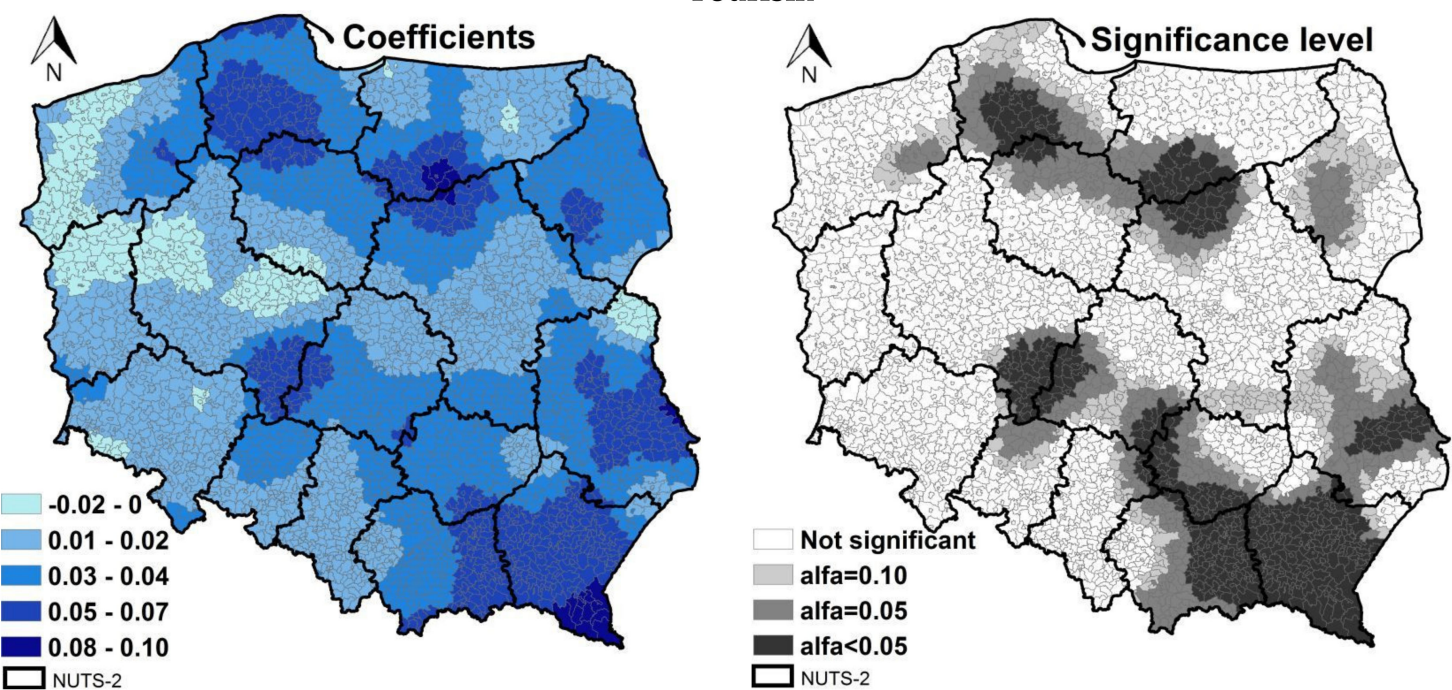

Working Age
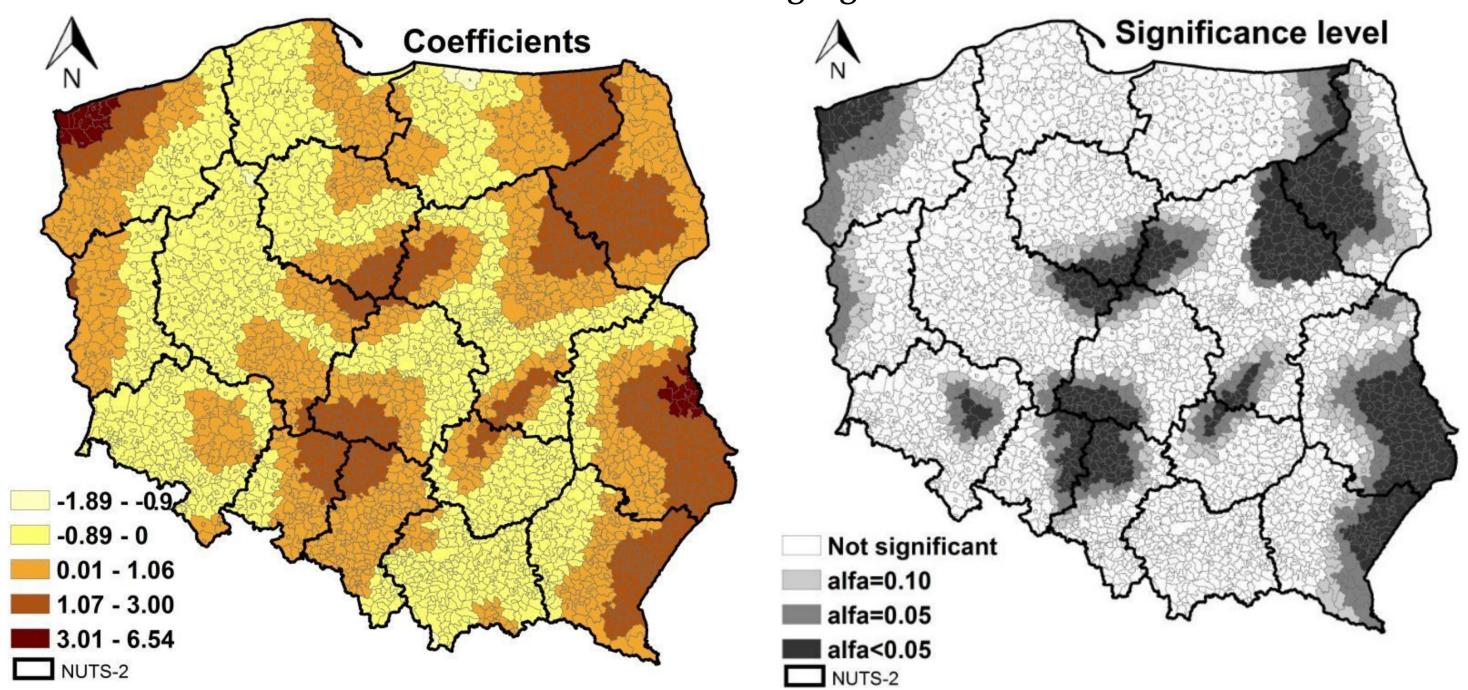

Figure 8. Cont. 

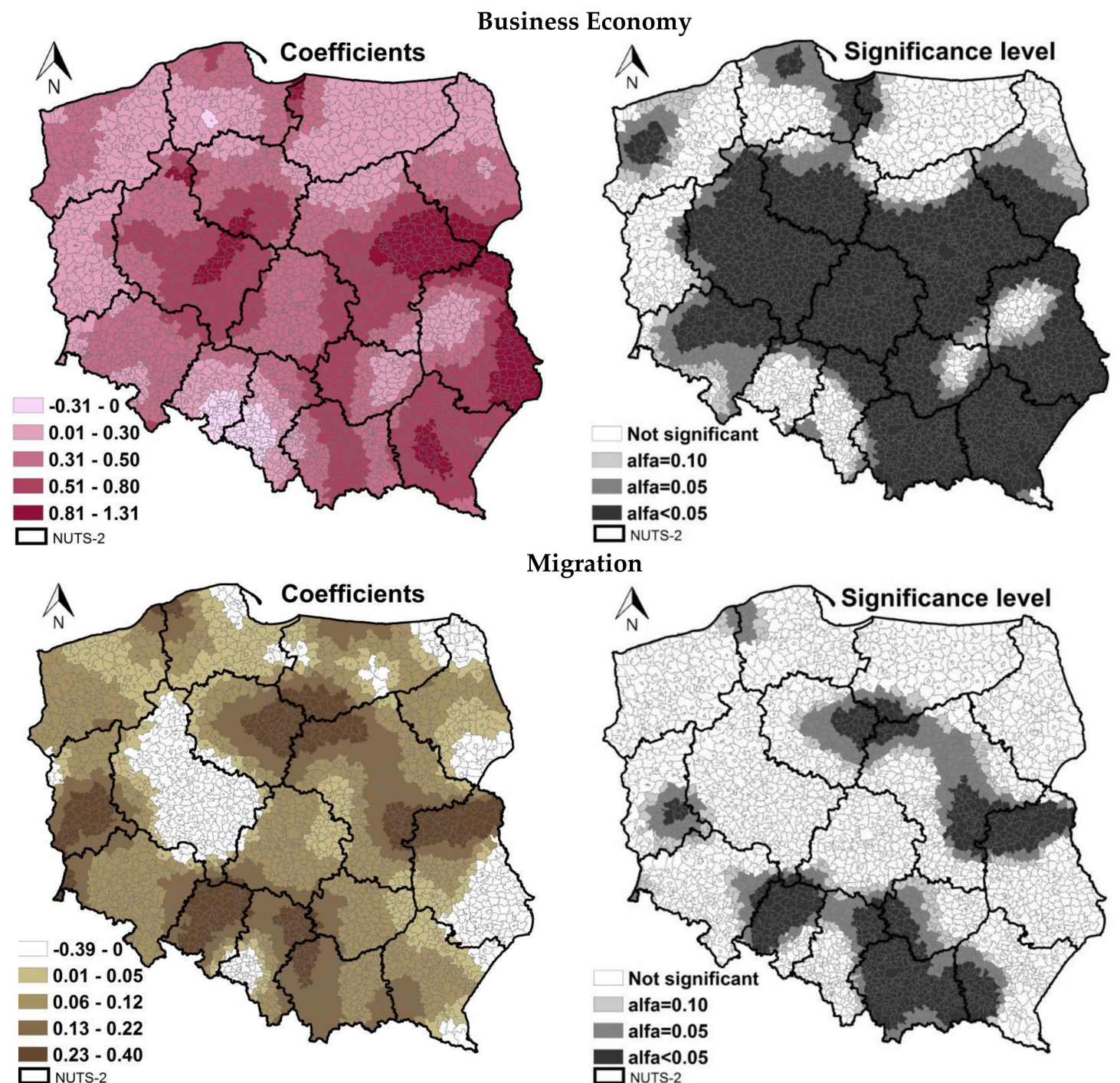

Migration

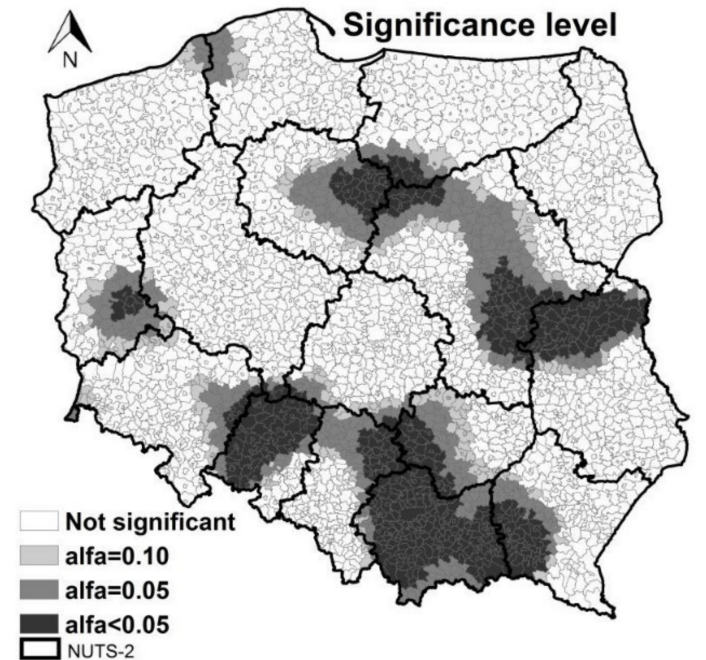

Higher Education
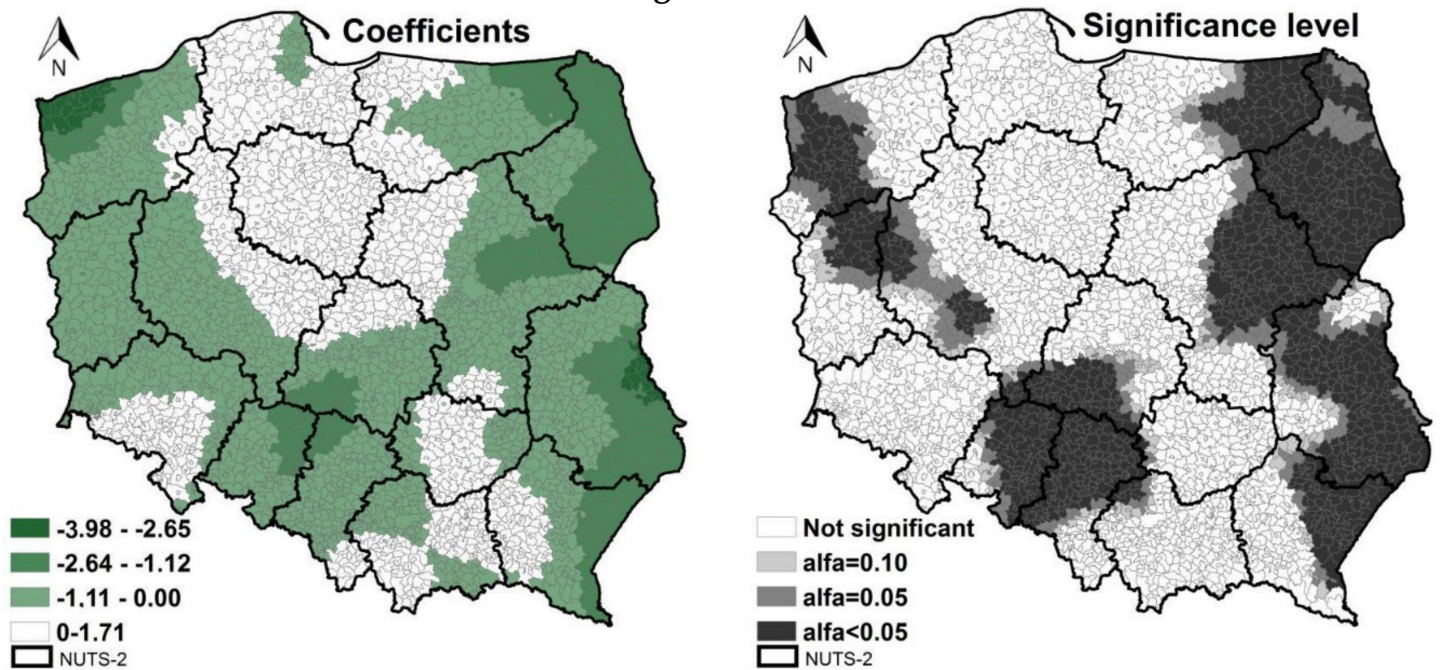

Figure 8. Local coefficients (a) and significance level (b) in the GWR-SEM models. Source: own elaboration in ArcGIS (ArcMap 10.6). 


\subsubsection{Urban Development}

The process of urbanization refers to the increasing proportion of people that live in urban areas. As urbanization increases, residents have easier access to retail outlets, so they tend to buy smaller quantities but more frequently, leading to an excess of packaging waste; moreover, urban households also have less storage and avoid storing easily replaceable items, choosing instead to discard them and repurchase them later when needed [75]. As a result, growing urban development increases the volume of municipal waste and waste disposal [23]. Poland is slowly de-urbanizing (the urbanization level in 2005 was $61.68 \%$, declining to $60.01 \%$ in 2018 ; the urban population declined by $1.81 \%$, while the rural population increased by $1.96 \%$ in the analyzed period, [76]), yet the urban population remains 1.54 times larger than the rural population. The modelling results revealed that the highest and most highly significant values of coefficients were observed for wealthier, highly populated urban areas of Poland-especially in the north (which is attractive to tourists), center, and south, which are characterized by high population density, naturalization, and strong urban and industrial centers. The high influence of urbanization on MW was also noted in some cities in the eastern parts of the country. The lowest values of coefficients were found in west and southeastern Poland, where the influence of the centuries-old partition of the country can be observed. Poland was partitioned among Austria (south), Prussia (west), and Russia (center and east); these three partitions differed significantly and provide an exogenous variation in institutional, inter-regional transmission of social, cultural, and technological norms in modern Poland. The Prussian state was above all a state of law, even though the administration discriminated against the Poles [77]. However, in this zone, the authorities carried out many reforms resulting in a good economic situation for Poles. Rising demand for agricultural products induced changes in agricultural technology, and as a result, agriculture rather than industry was the main driver of economic progress in those regions. In the Russian zone it was industry that developed the most. However, delayed manumission reforms contributed to the relative backwardness of the agriculture. The worst economic situation was in the Austrian part; this region had not been industrialized and agriculture was underinvested and parceled, with people experiencing poverty and bad economic conditions as a consequence [78]. The historical situation of the Polish minority in Prussia, Austria, and Russia can be therefore discussed in the context of contemporary urbanization and its influence on MW generation. Finally, the effect of urbanization on municipal waste volume sprawls into neighboring rural communes, though this influence is the strongest in terms of urban centers and weakens in rural areas (see the significance map in Figure 8). This phenomenon is associated with the depopulation of Polish cities and suburbanization processes [79].

\subsubsection{Housing}

Housing is one of the most important human needs and a considerable national asset, but also a leading generator of waste $[14,80]$. According to the Polish Central Statistical Office, in 2005, the housing stock comprised some 12.77 million dwellings, i.e., 303 dwellings per 1000 population, and it rose to 14.61 million in 2018, i.e., 330 buildings per 1000 population (an increase of 14\%) [81]. The results of the GWR-SEM modelling indicated that in 2005-2018, there was a positive correlation between the dwelling stock per 1000 inhabitants and the dependent variable in municipalities located in the west and central regions and in a few parts of the eastern Poland, as well as in some coastal zones (Figure 8). Generally, the highest values of coefficients (from $0.97 \%$ to $1.44 \%$ ) were observed in areas for which the highest level of dwellings per 1000 population or the most rapidly changing level of housing development were observed (on average, from 500 to 864 dwellings per 1000 population). According to the European Commission, the areas of eastern and northeastern Poland were characterized by the highest demand for dwellings due to the lowest transaction costs and prices in the country, as well as the fastest-increasing salaries [82]. According to the National Polish Bank, the housing stock in municipalities located in the west and central parts of Poland, where the values of coefficients ranged from $0.67 \%$ to $1.44 \%$, was driven by high salaries and a low unemployment rate [83]. Data presented on the maps in Figure 8 indicate that the influence of housing development on MW is often stronger in 
rural than in urban areas. During the analyzed time span, housing stock developed most rapidly in rural areas and around big cities or urban agglomerations, i.e., Warsaw, Poznan, Katowice, Kielce, or Lodz. In Poland, large cities have been attracting newcomers while losing their existing inhabitants to the neighboring communes (according to CSO data, the development of housing in rural units from 2005 to 2018 was only 2 percentage points lower than in urban areas; the housing stock in cites increased by $15 \%$ and in rural areas by $13 \%$ [81]). This has led to urban sprawl and the proliferation of suburbs, and a rise in waste volume [84].

\subsubsection{Tourism}

The European Environment Agency has acknowledged that despite the difficulties of quantifying the real impact of tourism on the environment, any rise in the number of tourists undoubtedly has an influence on waste generation and energy consumption (in terms of volume and local level) [85]. Accommodation and restaurants are major sources of tourist waste; furthermore, tourism waste often varies seasonally, and is collected in areas sensitive to littering, e.g., forests, parks, mountains, lakes, seas, and beaches. [86]. Despite the tourist sector generating only about $7 \%$ of all yearly collected municipal waste in Poland, the results of GWR-SEM modelling revealed that the number of nights spent by tourists per 1000 inhabitants was associated with increased municipal waste volume in various Polish communes. The greatest and most statistically significant impact of tourism on MW was observed in municipalities located in southeastern, northern, and north-eastern Poland (from $0.08 \%$ to $0.10 \%$ ), as seen in Figure 8. In 2005-2018, the aforementioned locations were characterized by the highest average number of overnight stays of visitors (from 2600 to 8900 nights per 1000 people) [87]. Those areas are attractive destinations thanks to their popular mountainous, coastal, and lake areas. The data presented on the map in Figure 8 indicate that the strong influence of tourism on municipal waste volume was also observed in communes located in central-western Poland-the region with many historical sites, industrial places, and castles. Moreover, this part of the country has become a valuable destination for business travel, due to its economic inclinations, geographic location, accommodation facilities, and an international airport [88]. Finally, the empirical findings suggested that an increase in the number of tourists resulted in a lesser (with a weaker statistical significance) increase in the waste generation (of about $0.03 \%$ to $0.07 \%$ ) in the communes located in the eastern part of Poland (Figure 8). The level of tourist visitation in the eastern part ranged from 150 nights to 714 nights per 1000 people [87]. However, this region's unique natural resources with diverse topography and places rich in flora and fauna led to rapid development of rural and agritourism in the eastern-situated communes [89].

\subsubsection{Working Age}

People of working age, as young adults, are the greatest consumers of material goods within a society [75]. They are therefore expected to have high waste quantities, as the positive estimate of the coefficient of the population age distribution suggests (Figure 8). In Poland, the working age community (15-64) makes up a significant share of the population (in 2005-2018, the average proportion of working-age people was 63\%, while the average in the European Union was 64.7\%). Data collected from the Polish Central Statistical Office indicate the share of the working-age population in municipalities increased from $61.7 \%$ in 2005 to $62.2 \%$ in 2018 [90]. Those changes in the population number were largely dependent on the location of a given municipality, influencing spatial diversification of the GWR-SEM coefficients. The strongest statistically significant relationship between higher proportion of people at working age and volume of MW was observed in the LAU-2 units located in northwestern and central Poland (from $3.01 \%$ to $6.54 \%$ ). The communes situated in those regions recorded the highest average share of working-age population over the studied period (from $65.1 \%$ to $72.7 \%$ ). Those areas are places of active socio-economic development and intense urbanization due to their high investment potential. Moreover, those zones recorded the highest level of the population's median income and the lowest rate of unemployment [91]. High values of coefficients (from 1.07\% to $6.54 \%$ ) 
were also observed in municipalities located in eastern parts of the country and formed two clusters in northern and southern Poland. During the analyzed time span, those units noted the fastest increase of working-age population (from 11\% to 19\%). Eastern Poland has strong academic, investment, and tourist potential [89]; moreover, from 2013 this region became a leader in the inflow of foreign workers from Ukraine, Belarus, and Russia (the Polish eastern agricultural sector has often been the first place where Eastern migrants acquire migration experience before relocating to other areas of living and employment) [92].

\subsubsection{Business Economy}

The results of the analysis indicated that the business economy (commerce and trade, office buildings, public administration institutions, and small businesses) had the greatest spatial range of "positive" impact on municipal waste generation (Figure 8). During the analysis period in Polish municipalities, on average 759 national economy entities were entered in the REGON system per 10,000 people (with a range of 179 to 4327 business units per 10,000 people). The highest concentration of entities was recorded in cities and metropolitan areas (deriving from their economy and regional specialization). According to the Polish Statistical Office, the number of companies increased by $17 \%$ between the years 2005 and 2018; nonetheless, that dynamic varied by location [93]. The highest increase was observed in municipalities located in central (in Warsaw, the Polish capital city) eastern, southern, and southwestern Poland (from 200\% to 300\% of enterprises during the time span). Although more and more businesses are implementing waste reduction activities, the companies are still heavily involved in spatially expansive waste generation in Poland. The highest positive correlation was noticed in municipalities situated in the border area with Ukraine, Belarus, and Slovakia-in southwestern Poland (the municipal waste volume increased there from $0.81 \%$ to $1.31 \%$, Figure 8 ). Since 2002, this microregion, because of its low level of socioeconomic development, has been one of the main recipients of operational funding programs and national development policy actions, which have resulted in a systematic increase in economic competitiveness and attractiveness of the area [94]. The highest values of coefficients were also observed in large cities along with the surrounding municipalities in east- and west-central Poland as well as in coastal cities. Those metropolitan areas (with their medium-sized and rural subregions) have become the fastest-developing and most important Polish hubs for employment in the business services and research and development sectors [95].

\subsubsection{Migration}

The generation of solid waste is a natural phenomenon of human civilization and is the inevitable consequence of population growth [76]. Migration processes shape human settlement patterns, population redistribution, and, therefore, population density [96]. According to data presented by the $\mathrm{CSO}$, the registration for permanent residency per 1000 people in Polish municipalities increased by 7\% from (11 per 1000 people to 12 per 1000 people) over the analyzed period. Moreover, population migration has changed from rural-urban to urban-rural (from 2005 to 2018 rural areas noticed an increase of about $10 \%$ in permanent residents). On average, most rural areas and small-sized cities located in subzones of Polish agglomerations noted an even higher number of registrations for permanent residency (from 17 to 63 per 1000 people) than those large cities themselves, as large Polish urban areas are experiencing suburbanization and sprawl [84]. However, these immigration phenomena (internal and foreign) are divergently distributed among municipalities. Moreover, the results of the GWR estimations reveal that registration for permanent residency unevenly accelerated the level of MW generation (Figure 8). The strongest relationship (in terms of significance and coefficient values) between registrations for permanent residency per 1000 people and waste production per capita was noted in western and south-eastern Poland (rising from $0.23 \%$ to $0.40 \%$ ). These rural regions are destinations of internal outmigration driven by educational opportunity [97]. A high positive correlation was also observed in municipalities located in the border area with Ukraine and Belarus in west-central Poland (in Warsaw and municipalities in its suburban areas). As mentioned above, those 
zones attract foreign workers from Eastern Europe [98]. Moreover, the capital city of Poland and its suburban regions remain a catchment city of intra-regional and intra-city migrations [99]. Finally, three clusters of high influence of migration processes on waste generation were also detected in northern and western Poland (increase of $0.13 \%$ to $0.22 \%$ ), as seen in Figure 8 . These are the areas with urban centers that generate permanent outflow to their closest rural surroundings [97].

\subsubsection{Higher Education}

The outcomes of GWR-SEM modelling confirmed that higher education is associated with reduced waste generation in Polish municipalities (Figure 8). Previous works have also revealed strong evidence for this relation, detecting that well-educated people contribute to a greater concern for the environment and are also more aware of the negative impact of their own behavior on health and the environment $[25,27,46]$. It could be assumed, according to whether waste generation or recycling is considered, that well-educated individuals may have more insight on the need to shift toward more sustainable and zero-waste consumption patterns [100]. According to OECD data, in Poland $92 \%$ of adults aged 25-64 have completed upper secondary education, higher than the OECD average of 78\% and among the highest rates in the OECD [101]. However, the negative correlation between graduates per 10,000 and waste volume was only confirmed for $39 \%$ of all studied communes (Figure 8). The strongest and most highly-significant impact was observed for units located in eastern and northwestern Poland (from $-3.98 \%$ to $-2.65 \%$ ). Municipalities located in the east-central and southern parts of the country also had high negative correlation between the explanatory and dependent variables (from $-2.64 \%$ to $-1.12 \%$ ). During the studied time period, clusters of municipalities in the eastern and central regions concentrated the largest number of people with graduate-level degrees (from 115 to 140 per 10,000 inhabitants), while the western and north-western parts of the country has the least (from 66 to 91 higher education graduates per 10,000 people). The eastern, central, and south-eastern regions of Poland are becoming popular trans-regional academic destinations with relatively low cost of living (many of the scientific institutions focus on education and research covering environmental, agriculture, and medical science [89]). Moreover, Poland's eastern part is called "the green lungs of Europe", and is an agricultural pillar of the Polish economy [94].

\section{Conclusions}

The primary objective of this study was to identify the determinants of municipal waste volume collected in 2478 Polish communes in 2005-2018. The analysis illustrates that over this specified period there was a steady growth and geographical variation of waste volume among municipalities in Poland. In 2005, noticeably more waste per capita was generated by the residents of cities, but the process unfolded over time at different rates for urban and rural areas. Moreover, MW among communes was biased not only by spatial heterogeneity (non-stationarity), but also by spatial dependence. To understand those regional inequalities, the modelling accounted for a range of factors. To control and explore the spatially varying relationships between quantity of municipal waste and socioeconomic determinants, the separate local geographically weighted models with error term were applied in this analysis (to show differences in the strength and direction of dependencies occurring between the analyzed variables in individual communes). The results of modelling detected that increases in urban development, housing, tourism, working-age population, business entities, and migration accelerated the production of waste. A negative correlation between high level of education and waste quantity was also observed. Urban growth and enterprise business development were the factors most involved in regional range affecting the waste quantity. The most influential, in terms of strength of association taking into account the strength, were higher education and the proportion of working-age individuals. The mapped GWR-SEM outputs detected clusters of factors spread over Polish communes influencing the quantity of municipal waste. Methodologically, the GWR-SEM approach described here constitutes a substantial advance over the use of traditional OLS methods to model local processes of waste generation. The GWR-SEM models identified spatially varying relationships between phenomena, 
highlighting the intricate patterns of influence and equity that simply cannot be identified using global OLS techniques. Local models were characterized by considerably better fit to the empirical data than were global ones (geographically weighted regressions explained about $98 \%$ of the variation in municipal waste production). Moreover, employing the spatial error component in the GWR enabled controlling for unobserved spatially-autocorrelated processes in modelling, closely connected to individual practices and waste management systems.

The findings of this study also suggest significant methodological and practical implications for locally-concentrated waste generation management and control. The results may be relevant for authorities seeking to implement better national and local policies aimed at promoting environmentally responsible behavior, selective collection and recycling, and waste minimization towards a circular economy for specific communes. Moreover, as this research focuses on the LAU-2 level and is publicly available, the municipal creators could therefore easily access and use the outcomes for planning new safe collection and disposal waste infrastructure, for predicting the future production of waste streams, or for supporting (improving and planning) the waste management system.

Although these study estimates have explained most of the variation in waste generation in Polish municipalities, there remain some possibilities to extend this analysis in the future. To explore the distances and directions of waste transport among LAU-2 in Poland, different spatial weights matrices (non-linear, asymmetrical, and with various rows of adjacency) could be built. Moreover, the regression analysis observed significant differences in MW volume between urban and rural areas. Future modelling for different sizes of cities and urban areas separately could further enrich the analysis. Moreover, accounting for the determinants of municipal waste by considering their structure (morphology) would benefit from further research. Finally, preparation of a survey to obtain more case-specific household data (e.g., housing characteristics, the average household income, environmental awareness, psychological factors that influence inhabitants' behavior, and consumption patterns) would present an opportunity to support future studies on municipal waste in Poland.

Author Contributions: Conceptualization, methodology, software, validation, formal analysis, investigation, resources, data curation, writing-original draft preparation, writing-review and editing, visualization, supervision, project administration, funding acquisition: E.A. I have read and agreed to the published version of the manuscript.

Funding: This research received no external funding.

Conflicts of Interest: I declare no conflict of interest. The funders had no role in the design of the study; in the collection, analyses, or interpretation of data; in the writing of the manuscript; or in the decision to publish the results.

\section{Appendix A}

Table A1. Descriptive statistics of the amount of municipal waste in Polish communes in years 2005-2018.

\begin{tabular}{cccccc}
\hline Year & Mean & Median & Std. Dev. & Max & Min \\
\hline 2005 & 178 & 132 & 85 & 484 & 1 \\
2006 & 185 & 143 & 84 & 487 & 1 \\
2007 & 191 & 152 & 83 & 527 & 1 \\
2008 & 187 & 144 & 82 & 609 & 1 \\
2009 & 189 & 148 & 84 & 694 & 1 \\
2010 & 188 & 149 & 83 & 660 & 1 \\
2011 & 189 & 154 & 77 & 598 & 1.3 \\
2012 & 188 & 157 & 74 & 579 & 1.5 \\
2013 & 197 & 174 & 70 & 613 & 5.8 \\
2014 & 216 & 197 & 73 & 539 & 3.3 \\
2015 & 225 & 209 & 75 & 949 & 4 \\
2016 & 238 & 223 & 74 & 773 & 5.2 \\
2017 & 246 & 227 & 74 & 773 & 6.3 \\
2018 & 253 & 236 & 77 & 805 & 11 \\
\hline
\end{tabular}


Table A2. Descriptive statistics of selected factors influencing the amount of municipal waste in Polish communes (averaged over years 2005-2018).

\begin{tabular}{cccccc}
\hline Variable & Mean & Median & St. Dev. & Min & Max \\
\hline UR & - & - & - & - & - \\
D & 315 & 307 & 51 & 202 & 864 \\
TO & 57 & 1 & 338 & 0 & 8913 \\
WA & 62.3 & 63 & 2.2 & 46.3 & 72.7 \\
EE & 1200 & 1075 & 514 & 189 & 6689 \\
M & 12 & 10 & 6 & 1 & 63 \\
ED & 105 & 103 & 19 & 66 & 141 \\
\hline
\end{tabular}

Table A3. Summary statistics for varying local coefficients of GWR-SEM regression.

\begin{tabular}{cccccc}
\hline Variable & Mean & Median & St. Dev. & Min & Max \\
\hline Intercept & -0.07 & -0.09 & 0.46 & -1.40 & 1.44 \\
UR & 0.13 & 0.13 & 0.07 & -0.11 & 0.36 \\
D & 0.40 & 0.43 & 0.42 & -1.02 & 1.44 \\
TO & 0.02 & 0.02 & 0.02 & -0.02 & 0.09 \\
WA & 0.22 & 0.05 & 0.87 & -1.89 & 6.54 \\
EE & 0.42 & 0.41 & 0.24 & -0.31 & 1.31 \\
M & 0.09 & 0.08 & 0.11 & -0.39 & 0.40 \\
ED & -0.33 & -0.18 & 0.77 & -5.98 & 1.71 \\
\hline
\end{tabular}

\section{References}

1. OECD. Municipal Waste. Available online: https://data.oecd.org/waste/municipal-waste.htm (accessed on 10 July 2020).

2. Eurostat. Municipal Waste Statistics. Available online: https://ec.europa.eu/eurostat/statistics-explained/ index.php/Municipal_waste_statistics\#Municipal_waste_generation (accessed on 10 July 2020).

3. European Environmental Agency. Eurostat: Environmental Data Centre on Waste. Available online: https://www.eea.europa.eu/themes/waste/links/eurostat-environmental-data-centre-on-waste (accessed on 10 July 2020).

4. Eurostat. Waste-Overview. Available online: http://ec.europa.eu/eurostat/web/waste (accessed on 10 July 2020).

5. Musmeci, L.; Bellino, M.; Cicero, M.R.; Falleni, F.; Piccardi, A.; Trinca, S. The impact measure of solid waste management on health: The hazard index. Annali dell'Istituto Superiore di Sanità 2010, 46, 293-298. [CrossRef] [PubMed]

6. United Nations. Transforming Our World: The 2030 Agenda for Sustainable Development. Available online: https://sustainabledevelopment.un.org/post2015/transformingourworld (accessed on 10 July 2020).

7. European Commission. Environment Action Programme to 2020. Available online: https://ec.europa.eu/ environment/action-programme/ (accessed on 10 July 2020).

8. United Nations. Sustainable Development Goals. Available online: https://www.un.org/ sustainabledevelopment/wp-content/uploads/2019/01/SDG_Guidelines_AUG_2019_Final.pdf (accessed on 10 July 2020).

9. Polish Local Data Bank of Central Statistical Office. Municipal Waste and Maintenance of Cleanliness and Order in Communes. Available online: https://bdl.stat.gov.pl/BDL/metadane/metryka/2840?back=True (accessed on 10 July 2020).

10. Ministry of the Environment. Awareness, Attitudes and Ecological Behavior of Poles. Available online: https: //www.mos.gov.pl/srodowisko/edukacja-ekologiczna/badania/badania-swiadomosci-ekologicznej/ (accessed on 10 July 2020). (In Polish)

11. Pires, A.; Martinho, G.; Chang, N. Solid waste management in Europe countries: A review of systems analysis techniques. J. Environ. Manag. 2011, 92, 1033-1050. [CrossRef] [PubMed] 
12. Ministry of the Environment. Waste Management. Available online: https://www.mos.gov.pl/fileadmin/user upload/mos/Aktualnosci/2017/grudzien_2017/Raport_z_badania_dot._gospodarki_odpadami_2017_r._. pdf (accessed on 10 July 2020). (In Polish)

13. European Environment Agency. Municipal Solid Waste (MSW) Management and Selected Policy Instruments in European Countries, 2001-2015. Available online: https:/www.eea.europa.eu/themes/waste/wastemanagement/municipal-waste-management-across-european-countries/table-3-1-municipal-solid (accessed on 10 July 2020).

14. Alwaeli, M. An overview of municipal solid waste management in Poland. The current situation, problems and challenges. Environ. Prot. Eng. 2015, 41, 181-193. [CrossRef]

15. Act amending the Act on Maintaining Cleanliness and Order in Communes and certain other acts (the "Draft Act") amending Act of 13 September 1996 on Maintaining Cleanliness and Order in Communes (consolidated text-Journal of Laws of 2018, item 1454), the Act on Waste of 14 December 2012 (consolidated text-Journal of Laws of 2018, item 992) and the Act of 20 February 2015 on Renewable Energy Sources (consolidated text Journal of Laws of 2018, item 2389). Available online: https://www.linklaters.com/pl-pl/insights/publications/ 2019/march/planned-amendments-to-the-waste-act-in-poland (accessed on 24 August 2020).

16. Przydatek, G. Assessment of changes in the municipal waste accumulation in Poland. Environ. Sci. Pollut. Res. 2020, 27, 25766-25773. [CrossRef] [PubMed]

17. Boer Den, E.; Jędrczak, A.; Kowalski, Z.; Kulczycka, J.; Szpadt, R. A review of municipal solid waste composition and quantities in Poland. Waste Manag. 2010, 30, 369-377. [CrossRef]

18. Smol, M.; Duda, J.; Czaplicka-Kotas, A.; Szołdrowska, D. Transformation towards Circular Economy (CE) in Municipal Waste Management System: Model Solutions for Poland. Sustainability 2020, 12, 4561. [CrossRef]

19. Beigl, P.; Lebersorger, S.; Salhofer, S. Modelling municipal solid waste generation: A review. Waste Manag. 2008, 28, 200-214. [CrossRef]

20. Bosire, E.; Oindo, B.; Atieno, J.V. Modeling Household Solid Waste Generation in Urban Estates Using SocioEconomic and Demographic Data, Kisumu City, Kenya. Available online: https://repository.maseno.ac. ke/handle/123456789/441 (accessed on 10 July 2020).

21. Oribe-Garcia, I.; Kamara-Esteban, O.; Martin, C.; Macarulla-Arenaza, A.M.; Alonso-Vicario, A. Identification of influencing municipal characteristics regarding household waste generation and their forecasting ability in Biscay. Waste Manag. 2015, 9, 26-34. [CrossRef]

22. Ramachandra, T.; Bharath, H.; Kulkarni, G.; Han, S.S. Municipal solid waste: Generation, composition and GHG emissions in Bangalore, India. Renew. Sustain. Energy Rev. 2018, 82, 1122-1136. [CrossRef]

23. Sterner, T.; Bartelings, H. Household waste management in a Swedish municipality: Determinants of waste disposal, recycling and composting. Environ. Res. Econ. 1999, 13, 473-491. [CrossRef]

24. Hage, O.; Söderholm, P. An econometric analysis of regional differences in household waste collection: The case of plastic packaging waste in Sweden. Waste Manag. 2008, 28, 1720-1731. [CrossRef] [PubMed]

25. Kolekar, K.A.; Hazra, T.; Chakrabarty, S.N. A review on prediction of municipal solid waste generation models. Procedia Environ. Sci. 2016, 35, 238-244. [CrossRef]

26. Vieira, V.H.A.D.M.; Matheus, D.R. The impact of socioeconomic factors on municipal solid waste generation in São Paulo, Brazil. Waste Manag. Res. 2018, 36, 79-85. [CrossRef] [PubMed]

27. Prades, M.; Gallardo, A.; Ibàñez, M.V. Factors determining waste generation in Spanish towns and cities. Environ. Monit. Assess. 2015, 187, 4098. [CrossRef] [PubMed]

28. Khan, D.; Kumar, A.; Samadder, S. Impact of socioeconomic status on municipal solid waste generation rate. Waste Manag. 2016, 49, 15-25. [CrossRef]

29. Mateu-Sbert, J.; Ricci-Cabello, I.; Villalonga-Olives, E.; Cabeza-Irigoyen, E. The impact of tourism on municipal solid waste generation: The case of Menorca Island (Spain). Waste Manag. 2013, 33, 2589-2593. [CrossRef]

30. Johnstone, N.; Labonne, J. Generation of household solid waste in OECD countries: An empirical analysis using macroeconomic data. Land Econ. 2004, 80, 529-538. [CrossRef]

31. Sung, H.-C.; Sheu, Y.-S.; Yang, B.-Y.; Ko, C.-H. Municipal Solid Waste and Utility Consumption in Taiwan. Sustainability 2020, 12, 3425. [CrossRef]

32. Caruso, G.; Gattone, S.A. Waste Management Analysis in Developing Countries through Unsupervised Classification of Mixed Data. Soc. Sci. 2019, 8, 186. [CrossRef] 
33. Shi, G.; Li, Q.; Zeng, D.; Zhang, Y.; Fei, Y.; Xie, Y. Influencing factors of domestic waste characteristics in rural areas of developing countries. Waste Manag. 2018, 72, 45-54. [CrossRef]

34. Bach, H.; Mild, A.; Natter, M.; Weber, M. Combining socio-demographic and logistic fac tors to explain the generation and collection of waste paper. Res. Conser. Recyc. 2004, 41, 65-73. [CrossRef]

35. Hockett, D.; Lober, D.J.; Pilgrim, K. Determinants of per capita municipal solid waste generation in the Southeastern United States. J. Environ. Manag. 1995, 45, 205-218. [CrossRef]

36. Cheng, J.; Shi, F.; Yi, J.; Fu, H. Analysis of the factors that affect the production of municipal solid waste in China. J. Cleaner Produc. 2020, 259, 120808. [CrossRef]

37. Tałałaj, I.A. The influence of chosen socio-economical factors on change of waste quantity in podlaskie province. Inżynieria Ekologiczna 2011, 25, 146. (In Polish)

38. Generowicz, A. Multi-Criteria Analysis of Waste Management in Szczecin. Pol. J. Environ. Stud. 2014, 23, 57-63. [CrossRef]

39. Cheba, K. Methods of forecasting changes in municipal waste production in case of cities. AUL Folia Oecon. 2014, 3, 223-229.

40. Ulfik, A.; Nowak, S. Determinants of Municipal Waste Management in Sustainable Development of Regions in Poland. Pol. J. Environ. Stud. 2014, 23, 1039-1044.

41. Kukuła, K. Municipal Waste Management in Poland in the Light of Multi-Dimensional Comparative Analysis. Acta Sci. Pol. Oeconomia 2016, 15, 93-103.

42. Klojzy-Karczmarczyk, B.; Makoudi, S. Analysis of Municipal Waste Generation Rate in Poland Compared to Selected European Countries. 2017. Available online: www.e3s-conferences.org/articles/e3sconf/abs/2017/07/ e3sconf_eems2017_02025/e3sconf_eems2017_02025.html (accessed on 7 July 2020).

43. Keser, S.; Duzgun, S.; Aksoy, A. Application of spatial and non-spatial data analysis in determination of the factors that impact municipal solid waste generation rates in Turkey. Waste Manag. 2010, 32, 359-371. [CrossRef]

44. Keser, S. Investigation of the Spatial Relationship of Municipal Solid Waste Generation in Turkey with Socio-Economic, Demographic and Climatic Factors. Available online: http://citeseerx.ist.psu.edu/viewdoc/ download?doi=10.1.1.632.5116\&rep=rep1\&type=pdf (accessed on 10 July 2020).

45. Antczak, E. Municipal Waste in Poland: Analysis of the Spatial Dimensions of Determinants Using Geographically Weighted Regression. Eur. Spat. Res. Policy 2019, 26, 177-197. [CrossRef]

46. Rybova, K.; Burcin, B.; Slavík, J. Spatial and non-spatial analysis of socio-demographic aspects influencing municipal solid waste generation in the Czech Republic. Detritus 2018. [CrossRef]

47. Rybova, K. Do Sociodemographic Characteristics in Waste Management Matter? Case Study of Recyclable Generation in the Czech Republic. Sustainability 2019, 11, 2030. [CrossRef]

48. Antczak, E. Regional Patterns in Dumping Sites in Poland-Analysis in Context of the New "Sustainable" Waste Policy. Pol. J. Environ. Stud. 2020, 29, 1037-1049. [CrossRef]

49. Kołsut, B. Inter-Municipal Cooperation in Waste Management: The Case of Poland. Quaest. Geogr. 2016, 35, 104-191. [CrossRef]

50. Cyranka, M.; Jurczyk, M.; Pajak, T. Municipal Waste-to-Energy plants in Poland-current projects. In Proceedings of the E3S Web of Conferences, Kraków, Poland, 17-19 May 2016. [CrossRef]

51. Anselin, L. Spatial Externalities, Spatial Multipliers, and Spatial Econometrics. Int. Reg. Sci. Rev. 2003, 26, 153-166. [CrossRef]

52. Ismaila, A.B.; Muhmmed, I.; Bibi, U.M.; Husain, M.A. Modelling Municipal Solid Waste Generation Using Geographically Weighted Regression: A Case Study of Nigeria. Int. Res. J. Environ. Sci. 2015, 4, 98-108.

53. European Commission. Background. Available online: https://ec.europa.eu/eurostat/web/nuts/background (accessed on 12 August 2020).

54. European Commission. Local Administrative Units (LAU). Available online: https://ec.europa.eu/eurostat/ web/nuts/local-administrative-units (accessed on 12 August 2020).

55. Anselin, L.; Florax, R.J. New Directions in Spatial Econometrics; Springer Science \& Business Media: Berlin, Germany, 1995.

56. Getis, A.; Jared, A. Constructing the Spatial Weights Matrix Using a Local Statistic. Geogr. Anal. 2004, 36, 90-104. [CrossRef]

57. Matthews, S.A.; Yang, T.C. Mapping the results of local statistics: Using geographically weighted regression. Demogr. Res. 2012, 26, 151-166. [CrossRef] 
58. Charlton, M.; Fotheringham, A.S. Geographically Weighted Regression; National Centre for Geocomputation: Maynooth, Ireland, 2009.

59. Fotheringham, A.S.; Brunsdon, C.; Charlton, M. Geographically Weighted Regression: The Analysis of Spatially Varying Relationships; John Wiley \& Sons: Hoboken, NJ, USA, 2003.

60. Tobler, W. A computer movie simulating urban growth in the Detroit region. Econ. Geogr. 1970, 46, $234-240$. [CrossRef]

61. Fotheringham, A.S.; Brunsdon, C.; Charlton, M.E. Geographically Weighted Regression: The Analysis of Spatially Varying Relationships; Wiley: Chichester, UK, 2002.

62. Fotheringham, A.S.; Brunsdon, C.; Charlton, M.E. Quantitative Geography: Perspectives on Spatial Data Analysis; Sage: London, UK, 2000.

63. Loader, C.R. Bandwidth selection: Classical or plug-in? Ann. Stat. 1999, 27, 415-438. [CrossRef]

64. Bowman, A. An Alternative Method of Cross-Validation for the Smoothing of Density Estimate. Biometrika 1984, 71, 353-360. [CrossRef]

65. Gollini, I.; Lu, B.; Charlton, M.; Brunsdon, C.; Harris, P. GWR model: An R Package for Exploring Spatial Heterogeneity Using Geographically Weighted Models. J. Stat. Softw. 2015, 63, 1-50. [CrossRef]

66. Ferré, J. Regression Diagnostics; Comprehensive Chemometrics; Brown, S.D., Tauler, R., Walczak, B., Eds.; Elsevier: Amsterdam, The Netherlands, 2009; pp. 33-89. [CrossRef]

67. Marquardt, D.W. Generalized inverses, ridge regression, biased linear estimation and nonlinear estimation. Technometrics 1970, 12, 591-612. [CrossRef]

68. Andy, M. The ESRI Guide to GIS Analysis. Volume 2: Spatial Measurements and Statistics and Zeroing. In Geographic Information Systems at Work in the Community; ESRI Press: Boston, MA, USA, 2005.

69. Leung, Y.; Mei, C.L.; Zhang, W.X. Statistical Tests for Spatial Nonstationarity Based on the Geographically Weighted Regression Model. Environ. Plan. Econ. Space 2000, 32, 9-32. [CrossRef]

70. Cho, S.H.; Lambert, D.M.; Roberts, R.K.; Kim, S.G. Demand for Open Space and Urban Sprawl: The Case of Knox County, Tennessee. In Progress in Spatial Analysis. Advances in Spatial Science (The Regional Science Series); Páez, A., Gallo, J., Buliung, R., Dall'erba, S., Eds.; Springer: Berlin/Heidelberg, Germany, 2010.

71. Lewandowska-Gwarda, K.; Antczak, E. Urban Ageing in Europe-Spatiotemporal Analysis of Determinants. ISPRS Int. J. Geo-Inf. 2020, 9, 413. [CrossRef]

72. Akinwande, M.O.; Dikko, H.G.; Samson, A. Variance Inflation Factor: As a Condition for the Inclusion of Suppressor Variable(s) in Regression Analysis. Open J. Stat. 2015, 5, 754-767. [CrossRef]

73. Hervé, A.L.; Williams, J.L. Principal Component Analysis. WIREs Comput. Stat. 2010, 2, 433-459.

74. Yu, D.-L. Spatially varying development mechanisms in the Greater Beijing area: A geographically weighted regression investigation. Ann. Reg. Sci. 2006, 40, 173-190. [CrossRef]

75. Jenkins, R.R. The Economics of Solid Waste Reduction; Edward Elgar Publishing Limited: Aldershot, UK, 1993.

76. World Bank. Urban Development. Available online: https://data.worldbank.org/topic/urban-development? end=2019\&locations=PL\&start=2003\&view =chart (accessed on 13 July 2020).

77. Becker, S.O.; Boeckh, K.; Hainz, C.; Woessmann, L. The Empire Is Dead, Long Live the Empire! Long-Run Persistence of Trust and Corruption in the Bureaucracy. Econ. J. 2016, 126, 40-74. [CrossRef]

78. Bukowski, P. How history matters for student performance: Lessons from the Partitions of Poland. J. Comp. Econ. 2018, 47, 136-175. [CrossRef]

79. Hlaváček, P.; Kopáček, M.; Horáčková, L. Impact of Suburbanisation on Sustainable Development of Settlements in Suburban Spaces: Smart and New Solutions. Sustainability 2019, 11, 7182. [CrossRef]

80. Friedman, A. Fundamentals of Sustainable Dwellings; Joan, W., Ed.; Island Press: Washington, DC, USA, 2012.

81. Local Data Bank of Polish Central Statistical Office. Housing Economy and Municipal Infrastructure. Available online: https://bdl.stat.gov.pl/BDL/metadane/cechy/szukaj?slowo=dwellings (accessed on 15 July 2020).

82. European Commission. Regional Innovation Monitor Plus. Available online: https://ec.europa.eu/growth/ tools-databases/regional-innovation-monitor/base-profile/podlaskie (accessed on 15 July 2020).

83. National Polish Bank. Convergence and differentiation processes in local markets and structural changes (comparison of 16 markets in Poland). Available online: https://www.nbp.pl/publikacje/materialy_i_studia/ 174_en.pdf (accessed on 15 July 2020).

84. Karwinska, A.; Böhm, A.; Kudłacz, M. The phenomenon of urban sprawl in modern Poland: Causes, effects and remedies. Zarzadzanie Publiczne 2018, 26-43. [CrossRef] 
85. European Environmental Agency. European Briefings-Tourism. Available online: http://www.eea.europa. eu/soer-2015/europe/tourism (accessed on 15 July 2020).

86. European Commission. Best Environmental Management Practice in the Tourism Sector. Available online: https://ec.europa.eu/environment/emas/takeagreenstep/pdf/BEMP-6-FINAL.pdf (accessed on 16 July 2020).

87. Local Data Bank of Polish Central Statistical Office. Tourist Accommodation Establishments and Their Occupancy. Available online: https://bdl.stat.gov.pl/BDL/metadane/cechy/szukaj?slowo=tourism (accessed on 16 July 2020).

88. Abram, M.; Sleboda, M. Directions the Development of Business Tourism in Poland-Issues of Sustainability. ECOCYCLES 2016, 2, 35-43. [CrossRef]

89. Baum, S. The Tourist Potential of Rural Areas in Poland. East. Eur. Countrys. Sciendo 2011, 17, 107-135. [CrossRef]

90. Local Data Bank of Polish Central Statistical Office. Population at Pre-Working (up to the Age of 17), Working and Post-Working Age by Sex. Available online: https://bdl.stat.gov.pl/BDL/metadane/cechy/szukaj?slowo= working (accessed on 17 July 2020).

91. Ciżkowicz, P.; Ciżkowicz-Pękała, M.; Pękała, P.; Rzońca, A. The Effects of Special Economic Zones on Employment and Investment: Spatial Panel Modelling Perspective. Economic Institute. National Polish Bank. 2015. Available online: https://www.nbp.pl/publikacje/materialy_i_studia/208_en.pdf (accessed on 17 July 2020).

92. Jaroszewicz, M. Migration from Ukraine to Poland the Trend Stabilises. 2018. Available online: https: //www.osw.waw.pl/sites/default/files/Report_Migration\%20from\%20Ukraine_net.pdf (accessed on 17 July 2020).

93. Local Data Bank of Polish Central Statistical Office. Entities of the National Economy, Ownership and Structural Transformations. Available online: https://bdl.stat.gov.pl/BDL/metadane/cechy/szukaj?slowo= REGON (accessed on 18 July 2020).

94. Operational Programme Eastern Poland 2014-2020. Available online: https://www.polskawschodnia.gov.pl/ media/10302/POPW_english_version.pdf (accessed on 18 July 2020).

95. European Commission. Warsaw Capital Region. Available online: https://ec.europa.eu/growth/toolsdatabases/regional-innovation-monitor/base-profile/warsaw-capital-region (accessed on 18 July 2020).

96. Rees, P.; Bell, M.; Kupiszewski, M.; Kupiszewska, D.; Ueffing, P.; Bernard, A.; Charles-Edwards, E.; Stillwell, J. The Impact of Internal Migration on Population Redistribution: An International Comparison. Popul. Space Place 2017, 23, 2036. [CrossRef]

97. Ilnicki, D. Rural Areas as the Origin and Destination of Permanent Internal Migrations between 2002 and 2017 in Poland. A Local-Level Analysis (Nuts 5). Quaest. Geogr. 2020, 39, 15-30. [CrossRef]

98. Cieślińska, B.; Dziekońska, M. The Ideal and the Real Dimensions of the European Migration Crisis. The Polish Perspective. Soc. Sci. 2019, 8, 314. [CrossRef]

99. Potrykowska, A. Population changes and internal migrations in Mazowieckie voivodship. Mazowsze Studia Regionalne 2018, 11-28. [CrossRef]

100. Zaman, A.U. A Strategic Framework for Working toward Zero Waste Societies Based on Perceptions Surveys. Recycling 2017, 2, 1. [CrossRef]

101. OECD. Better Life index. Poland. Available online: http://www.oecdbetterlifeindex.org/countries/poland/ (accessed on 20 July 2020).

(C) 2020 by the author. Licensee MDPI, Basel, Switzerland. This article is an open access article distributed under the terms and conditions of the Creative Commons Attribution (CC BY) license (http://creativecommons.org/licenses/by/4.0/). 